\title{
Bacopa monnieri (Linn.) Pennell - A Possible Plant for Impossible Diseases (A Review)
}

\author{
Abhishek Kumar Pandey \\ Department of Botany, Kalinga University, Raipur, India
}

Received January 3, 2021; Revised December 2, 2021; Accepted December 23, 2021

\section{Cite This Paper in the following Citation Styles}

(a): [1] Abhishek Kumar Pandey, "Bacopa monnieri (Linn.) Pennell - A Possible Plant for Impossible Diseases (A Review)," Advances in Pharmacology and Pharmacy, Vol. 10, No. 1, pp. 35 - 53, 2022. DOI: 10.13189/app.2022.100104.

(b): Abhishek Kumar Pandey (2022). Bacopa monnieri (Linn.) Pennell - A Possible Plant for Impossible Diseases (A Review). Advances in Pharmacology and Pharmacy, 10(1), 35 - 53. DOI: 10.13189/app.2022.100104.

Copyright $\bigcirc 2022$ by authors, all rights reserved. Authors agree that this article remains permanently open access under the terms of the Creative Commons Attribution License 4.0 International License

\begin{abstract}
Since the beginning of humankind, people are using numerous plants to cure diseases and abnormalities. Bacopa monnieri has been used by people for a long time. This plant has several medicinal and biochemical properties which would be beneficial to treat diseases. The current review article summarizes the medicinal, presence of the bioactive compound, mechanism of action, therapeutic importance, clinical trials, ethnobotanical usage, and distribution of the plant with respect to India and worldwide. Relevant information and literature on Bacopa monnieri were extracted from different sources and their finding were discussed in the manuscript. The number of therapeutic properties of the plant has been seen in the animal model experiment including anti-diarrheal, antioxidant, anti-inflammatory, anti-cancer, anti-fungal, anti-bacterial, anti-convulsant, hepatoprotective, antiulcer, anti-depressant, anti-hyperglycemic and anti-nociceptive activity, immunostimulatory activity, and wound healing activity. This article recapitulates ethnopharmacological uses of Bacopa monnieri to explore its therapeutic potentials thereby providing a basis for future research. Bacopa monnieri exhibits a comprehensive of pharmacological activities that could be observed by the presence of a vast range of chemical constituents. Manuscript also comprises tissue culture techniques and propagation of Bacopa monnieri. The study also provides a descriptive outlook on the uses of Bacopa monnieri in wastewater treatment. This review article highlights the endless possibilities present in the plant and also sheds light on research that has not yet been done on this plant and may prove useful if done in the future.
\end{abstract}

Keywords Bacopa monnieri, Medicinal Properties, Future Aspects, Bioactive Compounds, Ethnobotany

\section{Introduction}

Since the age of human civilization, we are using plants for treating different ailments. Ayurvedic medicine system had been established and practiced in India before $500 \mathrm{BC}$ according to Subhose et al., [1]. From ancient times to the modern age practicing herbal medicine is going on a large scale and is famous throughout the world since it has an almost negative impact on patients and low costs. According to a report by WHO, $80 \%$ of the world population depend on the herbal and traditional drugs for primary health care as already discussed by Kumar et al., [2]. Bacopa monnieri is also a medicinal plant that has been used for many purposes in the Ayurvedic medicine system. The present study summarizes all aspects of this plant.

\section{Morphology of the plant:}

Bacopa monnieri relates to the family of Plantaginaceae. It is a short, succulent, and perennial herb that normally grows on the bank of the river. The leaves are elongated, and 4-6 mm (0.16-0.24 in) thick, oblanceolate. An opposite leaf arrangement exists. Leaves are sessile, petiole less, dorsoventrally flattened alternate and spirally arranged. Leaf lamina is the entire type with an obtuse apex. The blossoms are little, actinomorphic, pedicellate, solitary, 
axillary, and white, with five petals. Sepals are five and unequal in size. Four stamens are presented in didynamous within the corolla tube. Length of leaves $4-5 \mathrm{~mm}$ and its width is about 0.6 to 0.9 . Similarly, the length of the petals is around $0.8 \mathrm{~mm}$ and the length of the pedicle is about $10 \mathrm{~mm}$ recorded by Vasu [3]. It prefers slightly marshy and wet conditions for cultivation. Stem propagation can be done easily. Each node arises a puff of roots. It starts blooming in the month of March and fruiting would be occurring in the month of May to June. Fig. 1 shows the morphological view of Bacopa monnieri.

\section{Scientific classification

$\begin{array}{ll}\text { Kingdom: } & \text { Plantae } \\ \text { Clade: } & \text { Tracheophytes } \\ \text { Clade: } & \text { Angiosperms } \\ \text { Clade: } & \text { Eudicots } \\ \text { Clade: } & \text { Asterids } \\ \text { Order: } & \text { Lamiales } \\ \text { Family: } & \text { Plantaginaceae } \\ \text { Genus: } & \text { Bacopa } \\ \text { Species: } & \text { B. monnieri }\end{array}$

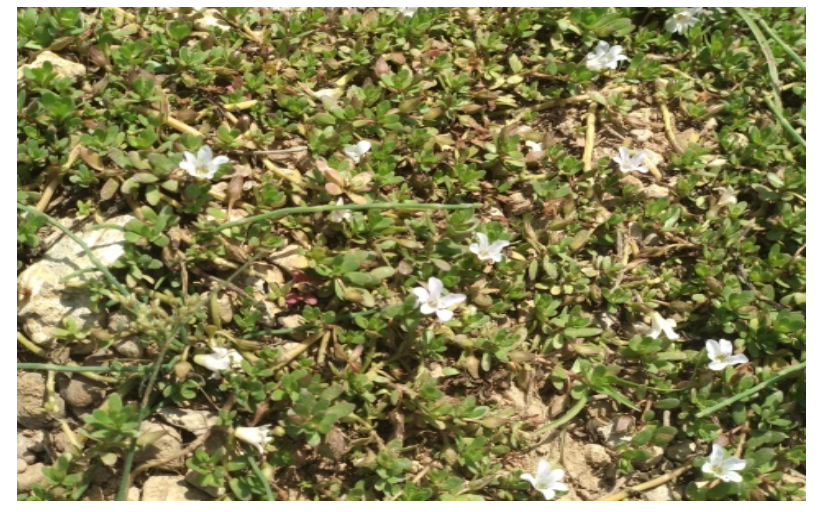

Figure 1. B. monnieri

\section{Anatomy of the plant}

Gubbannavar et al., [4] studied the anatomy of the plant. The transverse section of the stem revealed the outer epidermis followed by the cortex and endodermis. Two to three layers of hypodermis are made up of parenchymatous cells having chlorophyll and tannin-containing cell. Cortical cells modify and form aerenchyma which covers a two-thirds portion of the section. Tannin-containing cells are present at the connection side between two adjacent cells giving it a Y-like appearance. The endodermis is single-layered. The vascular system is radial. Xylem is present in numbers. Metaxylem is situated toward the pericycle and the protoxylem is situated toward the pith. Centrally located large pith is present.

T.S. section of leaf show outer layer epidermis. Lamina is differentiated into spongy and palisade. Three to five layers of palisade are present below the epidermis. Palisade and spongy cells are made up of chlorenchymatous tissue. The midrib portion consists of a vascular bundle. Crystal of calcium oxalate found in midrib and lamina. Stomata are diacytic and anisocytic types. Chromosome number of plant is recorded 2n=64 by Raghavan [5] in 1959.

\section{Distribution in India and Worldwide:}

This herb is distributed in the tropical and sub-tropical zone of India. It is native to the Himalayan zone such as Uttarakhand and Northeast. It also grows enormously in Chitrakoot Satna, Madhya Pradesh. It is distributed throughout the Indian subcontinent including Nepal, Bangladesh, and Pakistan. The presence of this herb is also reported in various other continents including Africa, America, and Australia.

\section{Description of Bacopa monnieri in Ayurveda}

In Ayurveda, this plant is known by the name of "Bramhi" which means knowledge deriving from gods. It is the most important and useful plant in the Indian system of traditional medicine used as a memory enhancer and sharpener. Bacopa has been used in various ailments including jaundice, diabetes, cough, leprosy, swelling, diabetes. It is also beneficial for treating skin and blood disorders. From ancient times this plant is used as a memory tonic and booster. The medicinal property of Bacopa monnieri has been mentioned in two famous books of Ayurveda i.e. Charak Samhita (2500 B.C) and Sushruta Samhita (2300 B.C) where it has mentioned that Brahmi removes toxic substances from the body along with giving intelligence, anti-inflammatory, strong memory, cooling. Apart from removing phlegm, it is also beneficial in skin-related diseases by purifying the blood P.V., [6]; Rai et al., [7]. Charak Samhita which is an important book on the Indian medicine system has mentioned the medicinal usage of this plant. This plant is used to cure throat infection, constipation, and blood filtering. It has been recommended for treatment of anxiety, lack of concentration, and poor cognition Russo et al, [8].

\section{Memory Enhancer Activity}

An animal trial has been performed by Joshi et al., [9] to assess the nootropic activity of Bacopa monnieri. Scopolamine $(0.4 \mathrm{mg})$ has been administered to induce amnesia in both young and aged mice. BacopaRasayana (An ayurvedic formulation of Bacopa monnieri) at doses of $100 \mathrm{mg}$ and $200 \mathrm{mg} / \mathrm{kg}$ of body weight administered for eight days. Elevated plus maze and passive avoidance paradigm were applied to evaluate the learning and memory enhancement in mice. Piracetum $200 \mathrm{mg}$ per $\mathrm{kg}$ of body weight is used as a standard drug. It has been noted BR enhanced memory and learning skills by decreasing acetylcholinesterase activity in the whole brain.

\section{Anti- Inflammatory Activity:}

Channa et.al, [10] showed anti-inflammatory activity 
action of Bacopa monnieri in carrageenan-induced paw edema in mice and rats. In this experiment, researchers used ethanol extract of Bacopa monnieri for treating inflammation. Inflammation action is induced by injecting carrageenan (1\%) into the right-hand paw. After thirty minutes animals received an ethanolic extract of BM at different concentrations. Anti-inflammatory activity was seen in Aspirin or 10\% DMSO. As result, it has been noticed by the author that BM extract cause significant decline $(33-95 \%)$ of paw edema at a dose of $50 \mathrm{mg} / \mathrm{kg}$ and $100 \mathrm{mgkg}$ that was more efficient than that caused by aspirin (28-60\%) Bacopashow anti-inflammatory activity by inhibiting prostaglandin $(58-100 \%)$.

It has been seen that when $\mathrm{N} 9$ microglial cell lines were treated with extract of B. monnieri, it prevented the secretion of pro-inflammatory cytokines (Tumor Necrosis factor-alpha) TNF- $\alpha$ and (Interleukin-6) IL-6 which are a major cause of inflammation in neuron cells, and ultimately it led to neuronal cell death. Tea fusion extract, alkaloid extract of Bacopa, and infusion extract were examined against the N9 microglial cell line in order to determine anti-inflammatory activity if they inhibited the release of the pro-inflammatory cytokines. Result reveals that tea, infusion, bacoside $\mathrm{A}$ and alkaloid extract significantly inhibited the release of inflammatory cytokines. The extract also inhibited the secretion of caspase-1 and matrix metalloproteinase-3 (enzymes responsible for inflammation) and caspase-3 in the cell-free assay and cleave the Tau protein major cause of Alzheimer's disease (Nemetchek et al. [11]. The study proved that Bacopa monnieri can control inflammation in the CNS.

Bacopa monnieri showed anti-inflammatory action in mice and prevents colchicine-induced dementia as demonstrated by Saini et al., [12]. They induced dementia by a single intracerebroventricular injection of colchicine $(15 \mu \mathrm{g} / 5 \mu \mathrm{l})$. A group of colchicine-treated animals was given an extract of Bacopa monnieri orally at the dose of $50 \mathrm{mg} / \mathrm{kg}$ body weight for the next 15 days on daily basis. Colchicine-treated animals with extract of BM showed a significant reduction in escape latency in comparison to only colchicine-treated animals and in the retrieval test, it has been found that BM administrated colchicine-treated animals effectively restore memory and rather than control.

\section{Anti-Oxidant Activity:}

Kapoor et al., [13] demonstrated antioxidant activity of Bacopa monnieri extract in streptozotocin-induced diabetic Wister albino male rats. In hyperglycemia conditions, free radicals are generated which leads to peroxidative damage to the tissues. This will increase the level of MDA (Malondialdehyde) a well-known compound of lipid peroxidation. The level of MDA has used an Index of oxidative injury which was performed by oxygen free radicals. In this study, the level of MDA has been checked in different parts of the body including the Kidney,
Cerebellum, Cerebrum, and Midbrain. After treating with Bacopa extract MDA level in the Midbrain region was significantly reduced from $2.96 \pm 0.19$ to 1.18 at $125 \mathrm{mg} / \mathrm{kg}$ body weight. In kidney region extract at a dose of $125 \mathrm{mg} / \mathrm{kg}$ performed maximum inhibition in MDA level has been seen. It reduced from $8.78 \pm 0.54$ to $6.20 \pm 0.05$. The same thing occurs in Cerebrum and Cerebellum region where MDA concentration has been reduced from $2.30 \pm 0.15,2.73 \pm 0.24$ to $1.45 \pm 0.02$ and $1.82 \pm 0.03$ at different doses respectively $125 \mathrm{mg} / \mathrm{kg}$ body weight and $50 \mathrm{mg} / \mathrm{kg}$ body weight which was better than the standard drug Glibenclamide.

Mathur et al., [14] evaluated the anti-oxidant activity of Bacopa extract through DPPH radical scavenging method and found methanolic and aqueous extract sho maximum anti-oxidant activity with IC50 value of $46.00 \mu \mathrm{g} / \mathrm{ml}$ and $43.10 \mu \mathrm{g} / \mathrm{ml}$ respectively.

Ramachandran et al., [15] demonstrated that an equal combination of extract of Bacopa monnieri and Rosmarinus officinalis has superior antioxidant potential and anti-lipid peroxidation in human glial (U-87MG) and embryonic mouse hypothalamus cells than either one of them has been used. This combination showed almost similar inhibition of phosphor tau expression as any one of the extracts does alone. This combination of the extract showed a better inhibitory effect on amyloid precursor protein synthesis and higher brain-derived neurotropic factor production in the hypothalamus than any single extract.

Ramdas et al., [16] performed a DPPH assay to evaluate the antioxidant activity of the plant. The researcher prepared various concentrations $(1-100 \mu \mathrm{g})$ of plant leaf protein, mixed it with $1 \mathrm{ml}$ of freshly prepared $0.5 \mathrm{mM}$ DPPH ethanolic solution and $2 \mathrm{ml}$ of $0.1 \mathrm{M}$ acetate buffer which has $\mathrm{pH}$ 5.5. BHA and Ascorbic acid were used as control. Bacopa monnieri shows the highest scavenging activity of DPPH radical at a dosage of $10 \mu \mathrm{g}$. The author also showed scavenging nitric oxide free radical which is also dose-dependent manner at a dose of 1 to $10 \mu \mathrm{g}$. Bacopa leaves protein at concentrated $10 \mu \mathrm{g}$ showed similar scavenging property against the ascorbic acid.

Neurodegenerative diseases are the result of harmful action of oxidative stress which causes inflammation and injury in a different region of brains and the main reason of oxidative stress is the production of reactive oxygen species. $\mathrm{H}_{2} \mathrm{O}_{2}$ is the precursor of deleterious oxygen species which causes serious brain injury by producing ROS. Bhatia et al., [17] addressed the problem and performed an experiment, and examine the neuroprotective role of Bacopa monnieri extract (BME) against $\mathrm{H}_{2} \mathrm{O}_{2}$ persuade oxidative stress using a cellular mode neuroblastoma IMR32 cell lines. Protective nature of methanolic ethanolic and water extract examined through MTT assay. Although all extracts had neuroprotective potential but methanolic extract had higher protection than other solvent extracts. UPLC study revealed that the methanolic fraction of Bacopa monnieri contains various 
polyphenols including quercetin, catechin, umbelliferace and caffeic acid. The levels of oxidative stress markers such as NF200, HSP70, and Mortalin were decreased at the same time. Finding suggests methanolic extract of Bacopa monnieri as an impactful drug against neuropathological disorders.

\section{Anti-Cancer Activity:}

Cancer is a very fetal disease worldwide impact human health adversely and contributes 10 million deaths in 2020 according to a report published by Ferlay J et al., [18]. Various anti-cancer agents including Cucurbitacins, Bacopaside I, Stigmasterol reported and evaluated in recent studies. Ghosh et al., [19] conducted a study to examine the Anti-tumor property of stigmasterol isolated from Bacopa monnieri. Stigmasterol at different doses $5 \mathrm{mg} / \mathrm{kg}$ of body weight and $10 \mathrm{mg} / \mathrm{kg}$ of body weight were given to Ehrlich Ascites Carcinoma mice against the standard drug S- fluorouracil at $25 \mathrm{mg} / \mathrm{kg}$ of body weight. Finding suggests stigmasterol as a potent anti-cancer agent. It not only decreases tumor volume but also diminished packed cell volume, viable cell count. After treatment with Bacopa extract life span of EAC tumor-bearing mice is increased. It is believed that stigmasterol control anti-tumor activity of cell by activation of protein phosphatase $2 \mathrm{~A}$ by ceramide which regulate apoptosis.

Mallick et al., [20] reported that Bacopa extract possesses an anticarcinogenic property by conducting an experiment over two different cell lines i.e. MCF-7and MDA-MB231. He found that the DCM fraction of ethanolic extract shows maximum cytotoxic activity up to 72 hours. The IC50 value DCM extract is $72 \mu \mathrm{g} / \mathrm{ml}$ for MCF-7 and $75.0 \mu \mathrm{g} / \mathrm{ml}$ for MDA-MB-231 cell lines. DCM fraction of extract show anti-cancer and anti-proliferative activity due to the presence of cucurbitacins and betulinic acid which arrest cell cycle at the G2/M phase

Mallick et al., [21] conducted a study to evaluate the anti-cancer properties of Bacopa extract by implementing in vitro and in vivo approaches. For conducting in vitro study different cancer cell lines from the colon (HT29, Coo320, Caco2) Lung (A549), cervix (HeLa SiHa), Breast (MCF-7, MDAMP-231) were selected. For conduction in vivo study, Ehrlich ascites carcinoma tumor having mice have been used. As a result, the dichloromethane fraction of extract showed a great response in both studies. In vivo studies, oral administration of $40 \mathrm{mg} / \mathrm{kg}$ of body weight rendered prominent reduction of tumor regression parameters such as tumor weight, packed cell volume tumor, volume, and viable tumor count as compared to the untreated mice of the EAC control group. In the case of in vitro study best cytotoxic activity has been recorded with DCM extract (41 to $60 \mu \mathrm{g} / \mathrm{ml}$ at 72 hours).

Smith et al., [22] found in their study that extract of Bacopa monnieri (Bacopa side II) discourage the growth of colon cancer cell in vitro by persuading cell cycle arrest and apoptosis. It has been observed that Bacopa side II blocked aquaporin I water channel expression in HT-29, SW480, SW620, HCT116 colon cancer cells. Inhibition of HT-29 at $20 \mu \mathrm{M}$ was predominantly mediated by $\mathrm{G} 0 / \mathrm{G} 1$ cell cycle arrest and at $30 \mu \mathrm{M}$ by G2/M arrest and apoptosis. Inhibition of SW480, SW620, and HCT116 at $\geq 15 \mu \mathrm{M}$ was mediated by $\mathrm{G} 2 / \mathrm{M}$ arrest and apoptosis.

\section{Anti-convulsant Activity:}

Brahmighrita (BG) and Saraswatarishtha (SW) two ayurvedic formulations contain Bacopa monnieri as the main ingredient was checked for anticonvulsant activity in Wister albino rats. In this experiment, animals were divided into four groups. The first group serves as blank received only water and feed ad libitum. Group 2nd received phenytoin as standard drug and group 3rd and fourth received Brahmi Ghrita (BG) $(0.9 \mathrm{ml} / \mathrm{kg})$ and Saraswatarishtha (SW) $(0.9 \mathrm{ml} / \mathrm{kg})$ orally for eight days in the morning time. Animals received convulsion after 1 hour of drug administration. Convulsion induced by Electro convulsometer. Maximal electroshock seizure was elicited by the application of electric shock $(60 \mathrm{~Hz} \mathrm{AC}$, $150 \mathrm{~mA}$ ) for 0.2 seconds using the corneal electrode. Symptoms of epileptic attacks like jerking grooming, tail Straub, an extension of the hind limb, and recovery were observed compared with the control and standard group. The result showed Brahmighrita produced a more significant impact in the phase of extension $(0.622 \pm 0.23 \mathrm{~S})$ and recovery $(2.221 \pm 0.04)$ compared to control whereas in jerking and tail straub significant reduction recorded in SG group by Giramkar et al., [23] at the end of the experiment.

\section{Antifungal Activity:}

Antifungal activity of plant extract was checked against Fusarium oxysporum, Alternaria species, Rhizocotonia solani, and Sclerotium rolfsii by Jain et al., [24] Different concentrations of plant extract were subjected to antifungal activity. Plant extract at various concentration i.e. $12.5 \mu \mathrm{g} / \mathrm{ml}, 25 \mu \mathrm{g} / \mathrm{ml}, 37.5 \mu \mathrm{g} / \mathrm{ml} 50 / \mu \mathrm{g} / \mathrm{ml} 62.5 \mu \mathrm{g} / \mathrm{ml}$ were added to the PDA media after autoclaving. It has been seen that plant extract at doses of $50 \mu \mathrm{g} / \mathrm{ml}$ and $62.5 \mu \mathrm{g} / \mathrm{ml}$ showed $100 \%$ inhibition against Fusarium oxysprum, Sclerotium rolfsii, Alternaria species, and Rhizootonia solani. IC50 value of the plant was recorded as $31.25 \mathrm{~g} / \mathrm{ml}$ against Fusarium oxysprum. Sclerotium rolfsii showed better antifungal activity exhibiting 90\%inhibition at $25 \mu \mathrm{g} / \mathrm{ml}$. IC50 value has been recorded for Sclerotium rolfsii is $6.25 \mu \mathrm{g} / \mathrm{ml}$ whereas IC50 for Alternaria was recorded $28.75 \mathrm{~g} / \mathrm{ml}$ and value of IC50 was recorded as $18.75 \mathrm{~g} / \mathrm{ml}$.

\section{Antibacterial Activity:}

Antibacterial activity has been evaluated in two parameters. MIC (Minimum inhibitory concentration) and disk diffusion, both methods were used to assess antibacterial properties against 9 different strains of 
bacteria which included gram-negative and gram-positive both by Ghosh et al., [25]. Minimum inhibitory concentration (MIC) was evaluated by broth dilution method by dissolving plant extract in DMSO as described previously. Different concentrations of plant extract in DMSO ranging from $25 \mu \mathrm{g} / \mathrm{ml}$ to $500 \mu \mathrm{g} / \mathrm{ml}$ have been prepared. The Agar disc diffusion method has been used for measuring the zone of inhibition. Different concentrations of $2,5,10 \mathrm{mg} / \mathrm{ml}$ of extract in DMSO prepared and the disc has dipped in mentioned concentration. Ciprofloxacin $(5 \mu \mathrm{g} / \mathrm{ml})$ has been used as a reference control for antibacterial activity. Bacopa extract at $10 \mathrm{mg} / \mathrm{ml}$ formed maximum zone of inhibition against various bacterial species including Staphylococcus aureus, Bacillus subtilis, Bacillus polymexia, Streptococcus faecalis, Pseudomonas aeruginosa, Salmonella typhi, Vibrio cholera, Shigella dysenteriae, Escherichia coli NCTC

\section{Antiulcer Activity:}

Swiss albino mice of male sex have been used by Karim et al., [26] for evaluating the anti-ulcer property of ethanolic extract of Bacopa monnieri. The animals were divided into nine groups each having 6 mice. Group 1st served as normal control only fed $0.5 \mathrm{ml} / 100 \mathrm{gm} 0.2$ tween 80. Group 2nd was given the same diet but treated to absolute alcohol $(0.5 \mathrm{ml} / 100 \mathrm{gm}$ of body weight $)$ Group $3 \mathrm{rd}$ was administered standard drug omeprazole $(20 \mathrm{mg} / \mathrm{kg}$ body weight) than alcohol $0.5 \mathrm{ml} / 100 \mathrm{gm}$. Group 4 th and Group 5th received aqueous extract of Bacopa monnieri at respective doses of $200 \mathrm{mg} / \mathrm{kg}$ body weight and $400 \mathrm{mg} / \mathrm{kg}$ body weight. Group 6th and 7th were administered ethanolic extract of plant respective doses of $200 \mathrm{mg} / \mathrm{kg}$ body weight and $400 \mathrm{mg} / \mathrm{kg}$ body weight. Group 8 th and 9th received carbon tetrachloride extract respective doses of $200 \mathrm{mg} / \mathrm{kg}$ body weight and $400 \mathrm{mg} / \mathrm{kg}$ body weight. All the extracts were given with $0.2 \%$ tween 80 . After one hour of treatment of extract, animals were administered with absolute alcohol to cause a gastric ulcers. Animals were sacrificed after one hour of alcohol treatment. Ulcer index was calculated according to the formula described by Brzozowski et al., [27]. The result show in group 2nd where no extract or drug had been used, ulcer index recorded highest $14.5 \pm 0.35$ which was significantly reduced by ethanolic extract of Bacopa monnieri. At doses of $200 \mathrm{mg} / \mathrm{kg}$ body weight ulcer index was recorded $3.13 \pm 0.38$ and protection was recorded at $78 \%$. And in $400 \mathrm{mg} / \mathrm{kg}$ doses of ethanolic extract of Bacopa monnieri maximum protection was recorded (82\%) from ulcer score and ulcer index was reduced at $2.75 \pm 0.32$.

\section{Antidepressant Activity}

Depression is a common mental illness in the world. According to a report of Lancet [28] around 32.2 crore people are suffering from this mental disease. Depression is also the main reason for committing suicide. Lots of diseases have oriented from this mental disorder including high blood pressure, heart attack, paralytic strokes, and diabetes so it is necessary to evaluate potent antidepressant agents from natural resources. Depression is the second-largest psychiatric problem which affects around $21 \%$ population of the world. Almost all people suffer at their different stages of life so it is necessary for us to search for potent anti-depressant agents from natural sources including plants for the betterment of mankind.

A number of studies have been performed that prove Bacopa monnieri possess anti-depressant property. The study suggests it is just because of the presence of bacoside I in plant extract of Bacopa monnieri Sairam et al., [29]. Anti-depressant activity of Bacopa monnieri has been evaluated in Charles-foster (CF) albino rats using behavioral despair test and learned helplessness test. The study reveals that methanolic extract of Bacopa monnieri at doses of $20 \mathrm{mg} / \mathrm{kg}$ body weight and $40 \mathrm{mg} / \mathrm{kg}$ body weight shows a significant decrease in the period of immobility induced by behavioral despair due to restrictive swimming by the rats. At the same doses, animals show good responses in learned helplessness tests by reducing escape failure. Bacopa monnieri show almost equal response standard drug imipramine $15 \mathrm{mg} / \mathrm{kg}$ of body weight. Antidepressant activity of this plant has been performed in albino mice. Bacopa monnieri produced a significant reduction in the duration of immobility at 80 $\mathrm{mg} / \mathrm{kg}$ dose.

In another study where the same result was obtained conducted Chandrashekaran [30] evaluated the anti-depressant activity of Bacopa monnieri reported in an animal model of Forced swimming test (FST) and tail suspension test (TST). The researcher reported a significant reduction in the duration of immobility at $80 \mathrm{mg} / \mathrm{kg}$ of body weight. It is believed that Bacopa mediated interaction with serotonergic and noradrenergic nervous system

\section{Anti-Alzheimer Activity of Plant}

An animal trial has been performed by Uabundit et al., [31] to see the impact of Bacopa monnieri extract on ethylcholine aziridinium induced Alzheimeric male Wister rats. Rats were tested for spatial memory using the Morris water maze test. Histological study was also performed to check the density of neurons and cholinergic neurons. Result reveals that BME improved escape latency time in Morris water maze test. The study suggests Bacopa monnieri is an impactful drug against Alzheimer disease.

\section{Anti -Alzheimer's activity of Bacopa monnieri in Human Clinical Trail}

Calabrese et al., [32] performed a study to evaluate the impact of Bacopa monnieri on cognitive performance anxiety and depression during elderly age by using a randomized double-blind placebo-controlled trial. 54 
volunteers having a mean age of 73.5 participated in this study out of which 48 remains at the end of the study. These 48 volunteers are divided into two equal groups. One group has received a placebo while the second group received a standard extract of Bacopa monnieri at the dose of $300 \mathrm{mg} /$ day received till 12 weeks. Different cognitive tests including auditory verbal learning test (AVLT), Stroop Task assessing the ability to ignore irrelevant information and the Divided Attention Task (DAT), and the Wechsler Adult Intelligence Scale (WAIS) letter-digit test of immediate working memory, State-Trait Anxiety Inventory, Center for Epidemiologic Studies Depression scale (CESD)-10 depression scale, and the Profile of Mood States. Vital signs were also monitored. The result shows that Bacopa participants had enhanced AVLT delayed word recalls comparison to the placebo group. Stroop result was also significant with the Bacopa group improving. CESD-10 depression scores, combined state plus trait anxiety scores, and heart rate decreased over time for the Bacopa group but increased for the placebo group. In rest all cases no significant changes have been noted. Goswami et al., [33] conducted a clinical trial on Alzheimer's disease patients to evaluate the Anti-Alzheimer properties of Bacopa monnieri. (Standard extract of Bacopa monnieri). Total 39 patients having a mean age of 65.23 years were given plant extract at doses of $300 \mathrm{mg}$ twice a daily till 180 days. Before starting this trial mini-mental state examination scales (MMSES) were recorded for all patients. MMSES includes an orientation of time, place and person, attention, and in their language component in terms of reading learning writing, and comprehension. The patient involved in this study shows significant improvement in the MMSES parameter at the end of the trial.

A randomized double-blind parallel phase $2 \mathrm{~b}$ study has been performed by Prabhakar et al., [34] to find out the efficacy of Bacopa monnieri against the standard drug Donepezil. 48 patients were participated in the study which received $300 \mathrm{mg}$ of Bacopa monnieri extract and $10 \mathrm{mg}$ dopenzil. Results were analyzed through Alzheimer's disease assessment scale cognitive subscale (ADAS-cog) and postgraduate institute (PGI) memory scale. No significant differences have been recorded between Bacopa monnieri and dopenzil which show Bacopa as a potent anti-Alzheimer agent.

McPhee et al., [35] performed a randomized, double blind, placebo controlled trail in 28 healthy older adults. Participants have to complete cognitive training (CT) 3 hours weekly for 12 weeks. Cognitive tasks, life satisfaction, memory complaints and mood were assessed and blood analyzed for serum brai derived neurotropic factor (BDNF) before and after 12 weeks of intervention. Bacopa monnieri has higher mean accuracy in image discrimination task and menan accurary is higher in spatial working memory task than placebo group. Although neuroimaging outcomes of white matter and grey matters conflicts the behavioral results.

\section{Hepatoprotective Activity}

The hepatoprotective activity of Bacopa monnieri has been examined in paracetamol-induced liver damage in Wister albino rats. In this study, animals were categorized into four groups. The first group received $5 \mathrm{ml} / \mathrm{kg}$ normal saline. The second group received the same dose. Except for the 1 st group, all received $500 \mathrm{mg} / \mathrm{kg}$ paracetamol for seven days. Group third received $300 \mathrm{mg} / \mathrm{kg}$ of ethanolic extract of BM whereas group fourth received standard drug silymarin $25 \mathrm{mg} / \mathrm{kg}$. After sacrificing different assays including serum glutamate oxaloacetate (SGOT), Serum glutamate pyruvate transaminase (SGPI) alkaline phosphatase (ALP) Bilirubin (Direct and Total) Cholesterol (total and HDL) have been performed to analyze the activity. Levels of SGOT, SGPT, ALP, Bilirubin, and cholesterol are used and index to evaluate liver damage. It has been recorded that ALP, SGOT, SGPI, Bilurubin and Cholesterol significantly reduced comparison to control along with significantly enhancement in the level of GSH, SOD, CAT and HDL cholesterol by Ghosh et al., [36] during this experiment:

Another study on hepatoprotective action of Bacopa monnieri has been conducted by Menon et al., [37] on Nitrobenzene induced liver damage in rats. Bacopa extract at a dose of $200 \mathrm{mg} / \mathrm{kg}$ of body weight given orally to induced liver damaged mice. Increased serum marker enzymes Aspartate, Transaminase, and Phosphatase were restored towards normalization significantly by the extract. Level of SOD CAT and GPx were significantly increased after treatment with Bacopa monnieri extract in liver injured experimental rats.

\section{Immunostimulatory effects of the medicinal plant}

The immune stimulatory effect of Bacopa monnieri has been evaluated by Yamada et al., [38] in four-week-old male Sprague Dawley rats. In this study, animals were divided into four groups of ten rats. Animals received $10 \mathrm{~g}$ of Bacopa per $\mathrm{kg}$ of rat feed, $10 \mathrm{~g}$ of Echinacea per $\mathrm{kg}$ of rat feed, and $10 \mathrm{~g}$ of Withania per $\mathrm{kg}$ of rat feed. Bodyweight and food intake was recorded in two days interval. After four weeks, animals were sacrificed by withdrawing blood from the abdominal aorta under light diethyl ether anesthesia. The spleen lymphocytes isolated from each dietary group were cultured in 100ml FBS/RPMI 1640 medium. Cellular concentration maintained to $2 * 106$ cell $/ \mathrm{ml}$ in 24 well microtiter plates. Cells were incubated at $37^{\circ} \mathrm{C}$ for 48 hours in the absence and presence of $10 \mathrm{ug} / \mathrm{ml}$, Concanavalin A, and lipopolysaccharides. The concentration of $\operatorname{IgA} \operatorname{IgG}$ and $\operatorname{IgM}$ was measured by ELISA. Results revealed that the production of IgA, IgG were significantly higher in the serum of rat-fed Bacopa compared to Echinacea and Withania and also much higher than control. These herbs also stimulate the production of antibodies in the presence of LPS or ConA. Bacopa produced higher concentration of various antibodies 
including $\operatorname{Ig} \mathrm{A}, \operatorname{IgG}, \operatorname{IgM}, \operatorname{IgE}$ in comparison to Echinacea, Withania.

\section{Antihyperglycemic Activity}

The antihyperglycemic activity was examined in streptozotocin-induced diabetic Albino Wister male rats by Taznin et al., [39]. Diabetic-induced mice were categorized into seven groups. Each group has received particular doses respectively $50 \mathrm{mg} / \mathrm{kg}, \quad 125 \mathrm{mg} / \mathrm{kg}, 250 \mathrm{mg} / \mathrm{kg}$. Standard drug glibenclamide is given to one group $@ 0.6 \mathrm{mg} / \mathrm{kg} \mathrm{BW} /$ day. The level of glucose was recorded on 1 st day after diabetic induction and the last day of extract treatment. A significant increase of glucose in blood level has been recorded after streptozotocin induction i.e. $250 \mathrm{mg} / \mathrm{dl}$ which was reduced by Bacopa extract at $125 \mathrm{mg} / \mathrm{kg} \mathrm{BW}$. A maximum $49.21 \%$ of reduction of blood glucose level has been seen after the treatment of diabetic rats whereas standard drug glibenclamide shows a $53.77 \%$ reduction in blood glucose level. The present study evaluated Bacopa monnieri extract as a potent antidiabetic agent.

\section{Antinociceptive Activity}

The analgesic activity has been evaluated by Siraj et al., [40] using the model of acetic acid writhing in swiss albino mice against the standard drug Diclofenac sodium at a dose of $25 \mathrm{mg} / \mathrm{kg}$ of body weight. At different doses i.e. $250 \mathrm{mg} / \mathrm{kg}$ of body weight and $500 \mathrm{mg} / \mathrm{kg}$ of body weight of crude extract were given to acetic acid-induced mice. The result shows $36 \%$ writhing inhibition caused by $250 \mathrm{mg} / \mathrm{kg}$ of extract whereas $500 \mathrm{mg} / \mathrm{kg}$ (body weight) of extract inhibited $61.33 \%$ writhing in mice.

The antinociceptive activity has been checked by Taznin et al., [39] in Swiss albino mice. The acetic acid-induced constriction method was used for evaluating antinociceptive activity. Animals were divided into six groups. Animals of all groups were given $1 \%$ acetic acid, $10 \mathrm{ml}$ per kg body weight through intraperitoneal injection for inducing abdominal pain. 1st the group which served as control, received vehicle only ( $1 \%$ tween 80 in water, $10 \mathrm{mg}$ per kg body weight) Group 2nd was administered standard antinociceptive drug aspirin @ $200 \mathrm{mg} / \mathrm{kg}$ body weight rest all groups (group 3rd to 6th ) received extract (a) $50,100,200,400 \mathrm{mg} / \mathrm{kg}$ of body weight. The number of constrictions induced by gastric pain in mice was then counted for the next 10 minutes. Bacopa Extract at $400 \mathrm{mg}$ concentration inhibit $53.4 \%$ abdominal constriction which has significantly higher than Aspirin group which inhibit $40.0 \%$ abdominal concentration at $200 \mathrm{mg} / \mathrm{kg}$ of body weight.

\section{Wound Healing Activity}

The wound healing property of ethanolic extract of Bacopa monnieri has been evaluated by using Wister Albino rat of the male sex by Ghosh et al., [41]. The excision wound model that has been explained by Shirwaikar et al., [42] was used in this experiment. The hair of the back skin was removed by using hair remover cream. A circular wound having a diameter of $10 \mathrm{~mm}$ has been formed under mild ether anesthesia. Animals were divided into three groups. 1st group served as negative control which received simple ointment i.p. whereas group 2 nd received ointment having plant extract $(10 \% \mathrm{w} / \mathrm{w})$ in simple ointment and the third group received nitrofurazone $(0.2 \mathrm{w} / \mathrm{v})$ as a standard drug in ointment considered as a positive control. The entire test samples were given daily till the 12th day. On the 12th of the wounding post-day wound healing activity has been checked for all samples. $47.42 \%$ of wound healing activity recorded for negative control (maybe due to the immunity of animals) 67.08\% wound healing activity recorded for BM extracts and $80.99 \%$ wound healing property are shown by standard drug nitrofurazone. The level of Hydroxyproline and DNA synthesis has been also checked in wound tissues. As rapid DNA synthesis has been required in wound tissues to overcome the damage. Hydroxyproline is a major component of protein collagen describe by Szpaz, [43]. Collagen is required for blood clotting. It has been found that after treatment of Bacopa extract and nitrofurazone content of Hydroxyproline in wound tissue has been increased and reached $112.80 \pm 2.01 \mathrm{mg} / \mathrm{g}, 117 \pm 1.41 \mathrm{mg} / \mathrm{g}$ respectively whereas it is only recorded in $71.11 \pm 1.85$. DNA content also triggered in wound tissue has been recorded in $6.44 \pm 0.31$ in the negative control, $9.97 \pm 0.40$ recorded in Bacopa extract and $11.2 \pm 0.58$ has been noted in the standard drug.

\section{Adaptogenic Activity}

Anti adaptogenic activity of Bacopa monnieri has been checked by Rai et al.,[44] using male Sprague-Dawley rats weighing 180-200 g. Stress was induced in mice by keeping them in a hemicylindrical tube having a diameter of $4.5 \mathrm{~cm}$ and $12 \mathrm{~cm}$ long for 150 minutes in case of acute stress (AS). For inducing chronic stress (CS) in animals same procedure is performed twice a day. Animals are divided into control non-stress group, AS group, and CS group and extract treating group for both AS and CS. Animals (AS and CS group) were fed with plant extract at different doses of $40 \mathrm{mg} / \mathrm{kg}$ and $80 \mathrm{mg} / \mathrm{kg}$ 9prior to the stress regimen for seven days. Animals were sacrificed at the end of the experiment. The blood plasma was used for evaluation of different parameters including glucose, triglyceride, alanine aminotransferase, (ALT) aspartate aminotransferase (AST), and creatinine kinase by using an autoanalyzer. Their high concentration caused stress conditions in animal beings which should be lowered by extract if they possess adaptogenic properties. The result showed AS exposed mice significantly increase the blood plasma level of glucose which was significantly decreased in AS group. In the CS group, no significant change has been recorded whereas a significant increase in plasma 
level glucose has been recorded in the extract-treated CS group. In the case of plasma level triglyceride, it has decreased in the CS group but no significant change has been observed in drug-treated groups. In plasma ALT level no significant change has been reported in the CS group but it has significantly decreased in AS group pretreated with Bacopa extract at $80 \mathrm{mg} / \mathrm{kg}$ of body weight. In AS and CS groups plasma level AST has been significantly raised but it has been significantly declined in the drug-treated AS and CS groups. In the case of plasma level of CK activity, It has significantly risen in AS and CS groups which have been lowered by a drug-treated group of AS and CS at $40 \mathrm{mg} / \mathrm{kg}$ of body weight and $80 \mathrm{mg} / \mathrm{kg}$ of body weight.

\section{Anti-diarrheal Activity}

Siraj et al., [40] evaluated the anti-diarrheal property of Bacopa monnieri using a model of castor oil-induced diarrhea in mice. Diarrhea symptoms showing mice were categorized into three groups. One group is administered only $1 \%$ tween 80 at a dose of $10 \mathrm{ml} / \mathrm{kg}$ of body weight serves as a control. The second group received standard drug Loperamide at a dose of $50 \mathrm{mg} / \mathrm{kg}$ of body weight treated as a positive control. The third and last group received a methanolic extract of a plant at a dose of $500 \mathrm{mg} / \mathrm{kg}$ of body weight. The result was analyzed by stool count per hour. It has been found at the end of the experiment that Bacopa monnieri extracts at doses of $500 \mathrm{mg} / \mathrm{kg}$ having a latent period of $1.16 \pm 0.16$ against standard drugs having a latent period of $2.28 \pm 0.20$ whereas normal control group shows a latent period of $0.75 \pm 0.06$. The latent period is the time gap of two diarrheal episodes which has significantly raised in Bacopa extract. Mean of feces are also recorded in this study which has significantly decreased in Bacopa extract at doses of $500 \mathrm{mg} / \mathrm{kg}$ which reduced from $7.6 \pm 1.43$ to $3.6 \pm 0.98$ whereas the standard group show feces mean with the value of $2.4 \pm 0.51$. Bacopa possesses numbers of phytochemicals out of which tannin has to be supposed for the presence of anti-diarrheal activity in the plant extract.

\section{Anti-helicobacter Activity}

Anti-helicobacter pylori activity of Bacopa monnieri extract was evaluated in vitro condition against the bismuth subcitrate which is known Anti-pyloric agent by Goel et al., [45]. At the concentration of $1000 \mu \mathrm{g} / \mathrm{ml}$ of Bacopa monnieri extract showed $75 \%$ inhibition against $\mathrm{H}$. pylori which is equal to Bismuth subcitrate. The study demonstrates that Bacopa monnieri extract increases the amount of prostaglandin E (PGE) and prostacyclin (PGI2). Bacopa monnieri extract at $100 \mu \mathrm{g} / \mathrm{ml}$ increased $40.8 \%$ PGE and PGI2. Both prostaglandins are special types of lipid which play an important role in protection of gastric mucosa.

\section{Anti-Toxic Effect}

Shahid et al., [46] performed a study and evaluated the beneficial effect of Bacopa monnieri extract on opioid-induced toxicity. Toxicity in rats was induced by administration of $20 \mathrm{mg} / \mathrm{kg}$ for 14 days and 21 days for street heroin. Methanolic extract of Bacopa monnieri extract was given to rats two hours before the opioid treatment. It has been noted that morphine and street heroin cause elevation of serum alanine aminotransferase, aspartate, aminotransferase, and creatinine. The three compounds also cause toxicity in the liver and kidney. Rats treated with Bacopa extract prevent the elevation in ALT, AST, and creatinine in comparison to standard drug Ascorbic acid.

\section{Anti-hypertensive \& Anti-allergic Activity}

Very few studies have been conducted till now which show limited cardiovascular action of Bacopa monnieri. When Bacopa extract at the dose of $20-60 \mathrm{mg} / \mathrm{kg}$ of body weight is given intravenous to the anesthetized rats, it decreases systolic and diastolic pressure without affecting heart rate in the study of Kamkaew et al., [47] Brahmi reduces blood pressure partly via releasing nitric oxide from the endothelium, with additional actions on vascular smooth muscle $\mathrm{Ca}^{2+}$ homeostasis. Onsa-ard et al., [48] performed a clinical trial to see the anti-hypertensive activity of Bacopa monnieri against L-NAME administered Male Wister rats. Captopril was used as a standard drug in this experiment. Systolic blood pressure which attains elevation of $94.7 \pm 7.5 \mathrm{mmHg}$ (week $0, \mathrm{n}=7$ ) to $166.6 \pm 3.5 \mathrm{mmHg}$ can be reduced to $129.9 \pm 6.8 \mathrm{mmHg}$ after the treatment of Bacopa extract whereas in the case of standard drug captopril from $166.4 \pm 7.2 \mathrm{mmHg}$ (week 4) to $140.4 \pm 5.8 \mathrm{mmHg}$ (week $8, \mathrm{P}<0.01, \mathrm{n}=6-7$ ) but had no effect on normotensives. It is to be believed Brahmi extract elicited endothelial independent vasorelaxation, suggesting that it acts directly on the vascular smooth muscle cells.

A study has been conducted by Samiulla et al., [49] showed that methanolic extract of Bacopa leaves has a potent mast cell stabilization effect comparable to disodium cromoglycate. This result proves that Bacopa has anti-allergic properties.

\section{Anti-Parkinsonian effect}

Anti- Parkinsonian effect of Bacopa monnieri was evaluated by Jadiya et al., [50]. It has been seen that in the case of neurodegenerative Parkinson's disease, the accumulation of protein alpha-synuclein ultimately leads to the death of dopaminergic neurons. In this study researcher used Caenohabiditis elegans; a transgenic model expressing different strains of human alpha-synuclein [NLS901 (Punc 54: alpha synuclein YFP+ VNC-119 and pharmacological model expressing green fluorescent protein (GFP).

Babita Singh et al., [51] also checked neuroprotective role of Bacopa monnieri. In their study, they found Bacopa extract reduced the reactive oxygen species [ROS], decreased the pro inflammatory cytokines, and decreased 
the level of alpha synuclein in male Wister Albino rats. Study outcomes suggest Bacopa control inflammation in brain region and thus it can consider as novel therapeutics against Parkinson's disease.

\section{Antifertility Activity}

Antifertility activity of plant extract was evaluated in mice (Parkes Strain) by Akanksha et al., [52]. The study reveals that Bacopa extract at a dose of $250 \mathrm{mg} / \mathrm{kg}$ of body weight cause antifertility in mice by making reduction in mobility, viability morphology of spermatozoa in cauda epididymidis. Bacopa extract caused alternation in seminiferous tubules including intraepithelial vacuolation, loosening of germinal epithelium, and exfoliation of germ cells. The study also reveals that extract of Bacopa monnieri caused a significant reduction in the height of germinal epithelium and diameter of the seminiferous tubules compared to control.

\section{Anti-aging Activity}

Saha et al., [53] conducted a study for evaluation of the anti-aging activity of Bacopa monnieri. They found that Bacopa diminished the Benzo[a] pyrene-induced apoptosis and senescence in human astrocytes. In previous study it has already reported that Benzo[a]pyrene is a neurotoxic agent, responsible for impaired neuronal development, induced apoptosis which is the main cause of aging. Bacopa monnieri also prevents cell cycle arrest induced by Benzo[a]pyrene and protects the cell from reactive oxygen species. The formation of ROS also triggers by B[a]P by reducing the damaged mitochondria.

\section{Anti-emetic Properties}

Ullah et al., [54] conducted a study to see the anti-emetic properties of Bacopa monnieri. Both metanolic and butanolic fractions of Bacopa monnieri had been tested for anti-emetic property in chemotherapy induced emesis in Suncus murinus. Cisplatin $(30 \mathrm{mg} / \mathrm{kg})$ was injected to the animal for induction of emesis. Different concentration of Butanolic extract $(5-20 \mathrm{mg} / \mathrm{kg})$ and methanolic extract $(10-40 \mathrm{mg} / \mathrm{kg})$ were evaluated for anti-emetic screening. The result showed butanolic extract antagonized vomiting response $59.4 \%$ and methanolic extract counter it by $71 \%$. It suggests methanolic extract as a good source of the anti-emetic drug against chemotherapy-induced emetic condition.

\section{Side Effect \& Cytotoxic Activity}

Bacopa monnieri has been using in India for a long time. Till now none of the side effects has been recorded. Joshua Allan et al., [55] conducted a study to evaluate the safety and efficacy of BacoMind which is an enriched phytochemical composition of Bacopa monnieri. Bacopa monnieri recorded median lethal dose after administration of $2400 \mathrm{mg} / \mathrm{kg}$ of bodyweight in Sprague Dawley rats whereas no sign of toxicity or significant changes with respect to neurological examination, food consumption, body weight gain, hematological and blood biochemistry parameters had been observed in case of subchronic toxicity. Again acute and chronic toxicity of Bacopa monnieri has been checked in Sprague Dawley rats by Sireeratawong et al., [56]. Female rats were administered a single dose of $5000 \mathrm{mg} / \mathrm{kg}$ of body weight. Rats were monitored for 14 days. No abnormalities in behavior and health were recorded in this period. In chronic toxicity, both male and female rats were administered different doses of extract $(30,60,300$, or $1,500 \mathrm{mg} / \mathrm{kg})$ for 270 days. During these days health and behavior of animals were observed. At the end of the experimental animals were sacrificed. Body and organ weight were measured. Different parameters including hematology, blood clinical chemistry, and microanatomy have been examined. No significant differences have been reported between experimental and control group rats which established Bacopa monnieri extract as a safe drug. Cytotoxic activity has been evaluated by Siraj et al., [40] by using brine shrimp lethality bioassay. The extract shows $50 \%$ (L50) mortality at $26.30 \mu \mathrm{g} / \mathrm{ml}$ and $90 \%$ (L90) mortality at $141.25 \mu \mathrm{g} / \mathrm{ml}$.

\section{Pharmacognostic \&Physiochemical Properties}

Phompittayarat et al., [57] performed a study to see the seasonal impact of saponin content in Bacopa monnieri and recorded the highest saponin quantity in the rainy season while the highest weight yield was recorded in summer. A high quantity of saponin $[1.91 \pm 0.48 \mathrm{w} / \mathrm{w}]$ was detected at the shoot of Brahmi. The physiochemical property includes solubility of extract in different solvents, loss on drying, total Ash value, Acid insoluble ash, water-soluble ash. Extractive value of Bacopa monnieri in methanol recorded $10.1 \%$ followed by ethanol $8.6 \%$, water $7.6 \%$, chloroform $2.0 \%$, Acetone $1.5 \%$, Dichloroethane $0.6 \%$, and petroleum ether $0.5 \%$. Total ash value recorded $13.5 \%$, insoluble ash value $5.5 \%$, Water soluble ash value $2.5 \%$, and loss on drying recorded $1.5 \%$ by Pawar et al., [58].

Pharmacognostic Characterization of Bacopa monnieri has been done by Chaurasia et al., [59]. They did powder analysis which showed the presence of cuticle, raphide calcium late crystal, and starch in the plant. However, stone cells are absent. Fluorescence analysis was also performed by the researcher which was cited below. 
Table 1. Fluorescence study conducted by Chaurasia et al., [59]

\begin{tabular}{|c|c|c|c|c|}
\hline Sr.No. & Sample & FTC & Visible Light & DAPI \\
\hline 1 & Plant Powder & White & Yellow & White \\
\hline 2 & Plant Powder $+\mathrm{H}_{2} \mathrm{O}$ & Light green fluorescence & Dark brown & White \\
\hline 3 & Powder with $\mathrm{H}_{2} \mathrm{SO}_{4}$ & Light green fluorescence & Dark brown & Brown \\
\hline 4 & Powder with $\mathrm{NH}_{3}$ & Light green fluorescence & Dark green & White Fluorescence \\
\hline 5 & Powder with $\mathrm{C}_{2} \mathrm{H}_{5} \mathrm{OH}$ & Light green fluorescence & Brown & White \\
\hline 6 & Plant Powder $+\mathrm{KOH}$ & Light green fluorescence & Greyish Brown & Red \\
\hline 7 & Plant Powder with $\mathrm{NaOH}$ & Dark green fluorescence & Brick red & Brick Red \\
\hline 8 & Powder + Iodine & Light green fluorescence & White & White \\
\hline
\end{tabular}

Phrompittayarat et al., [60] compared various extraction methods and found that Bacopa monnieri gave the highest yield of Bacopa saponin if it is soaked in 95\% methanol for 3days after maceration. Content of Bacopa saponin evaluated through HPLC.

Silpa et al., [61] reported that drying of fresh herbage (Bacopa monnieri) at 50C of $12 \mathrm{~h}$ in cabinet drier retained the highest Bacoside content.

\section{Phytochemical and Bioactive Compound}

Phytochemical study reveals that plant possess numbers of phytoconstituents in it. It contains proteins $(10.54 \pm 1.71)$ $\mathrm{mg} / \mathrm{gm}$ carbohydrate $(150.63 \pm 6.61) \mathrm{mg} / \mathrm{gm}$., phenols (3.71 \pm 0.23$) \mathrm{mg} / \mathrm{gm} ., 2.03 \pm 0.11 \mathrm{mg} / \mathrm{gm}$, flavonoid (1.12 $\pm 0.02) \mathrm{mg} / \mathrm{gm}$. Numbers of bioactive compounds were isolated and identified from the plant extract. It also contains saponins, cardiac glycosides, steroids, tannins, phlobetanin and terpenoid.

Sivaramakrishna et al., [62] isolated two triterpenoids glucosides along with 10 known saponins. These triterpenoids glucosides are 3-O-[beta-D-glucopyranosyl-(1-->3)-beta-D-glucopyranos $\mathrm{yl}$ jujubogenin (1) and 3-O-[beta-D-glucopyranosyl-(1-->3)-beta-D-glucopyranos yl] pseudojujubogenin (2). Their structures were elucidated by NMR spectroscopy and chemical correlation.

Bhandari et al., [63] isolated a new sterol glycoside, bacosterol-3-O- $\beta$-D- glucopyranoside along with Bacopa saponin-C, Bacopa side-I, Bacopa side-II, bacosterol bacosine and luteolin-7-O- $\beta$ - glucopyranoside from Bacopa monnieri. Identification of structure has been done by using IR, 1D, 2D NMR (HMQC, HMBC, COSY) HR-ESI, QTOP MS and EI mass spectral techniques.

Estimation of twelve Bacopa saponin in Bacopa monnieri extract had performed by Murthy et al., [64] through developing a new method based on reversed-phase high-performance liquid chromatography.

Bhandari et al., [65] isolated cucurbitacin (A-E) from the aerial part of Bacopa monnieri. Structures were identified by using 1D, 2D NMR, ESI-QTOF-MS/MS.

Shefin et al., [66] demonstrate that Bacopapossess number of phytochemicals. Jeysari et al., [67] listed these phytochemicals in his study. According to the study Bacopapossess 52 phytoconstituents including Nicotine, D- Mannitol, Bacoside A, Bacopa saponin A, Bacopa saponin B, Bacopa saponin C, Bacopa saponin D, Bacopa saponin E, Bacopa saponin F, Bacopa saponin G, Bacopa side I (Fig. 2.7), Bacopa side II (Fig. 2.8), Bacopa side III, Bacopa side IV, Bacopa side VIII, Bacopa side XII, Plantainoside B, Betulinic acid, Cucurbitacin A, Cucurbitanic B, Cucurbitacin C, Cucurbitacin D, Cucurbitacin E, Steraic Acid, Rosavin, 3-4 Dimethoxycinnamic acid, Ascorbic acid, Aciatic acid, Brahmic acid, Wogonin, Oroxidin, Laliolide, Stigmasterol, $\beta$-sitosterol, Bacosterol, Bacosine, Heptacosane, Octacosane, Nanocosane, Triacontance, Hentriacontane, Dotriacontane, Apigenin, Quercetin, Ursolic acid, Luteolin, Asiaticoside, Bacopa side VI and Bacopa side VII, Bacopa side A3 (Fig. 2.1).

Jain, Paras; et al., [23] showed that total 37 compound are present in this plant including Phytol (Fig. 2.6), Tridecane, Octadec 9- enoic acid, (Fig. 2.2) N-hexadecanoic acid, Stigmasterol (Fig. 2.3), Vitamin E (Fig. 2.10), Icosanoic acid (Fig. 2.5), cis-9- hexadecenal acid (Fig. 2.4), Dodecane, phenol, 2 methoxy-4-(2 propenyl), 2- Nonenal, 2-pentyl, 2,6,10rimethyl,14-ethylene-14-pentadecene,Hexaecanoic acid, Methyl ester, Octadecanoic acid (Fig. 2.9), Ergost-5-en-ol, (3- $\beta-24 \mathrm{R})-$, Hahnfett, Hneicosane Cis-10-Nonadecenoic acid.

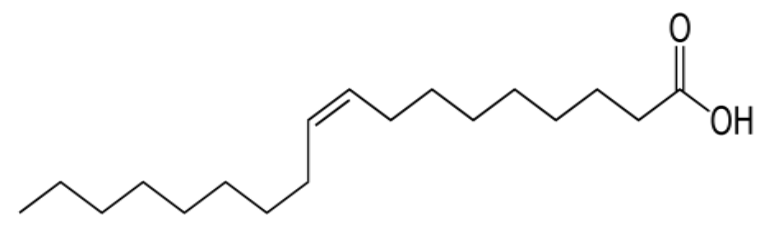

Figure 2.1. Bacoside A3 


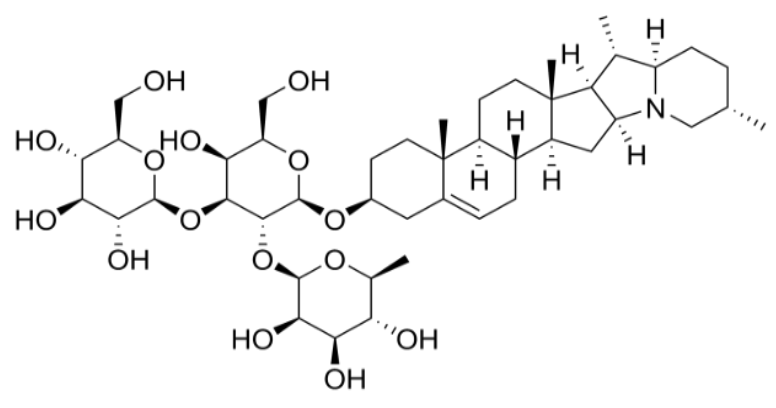

Figure 2.2. Octadec 9- enoic acid

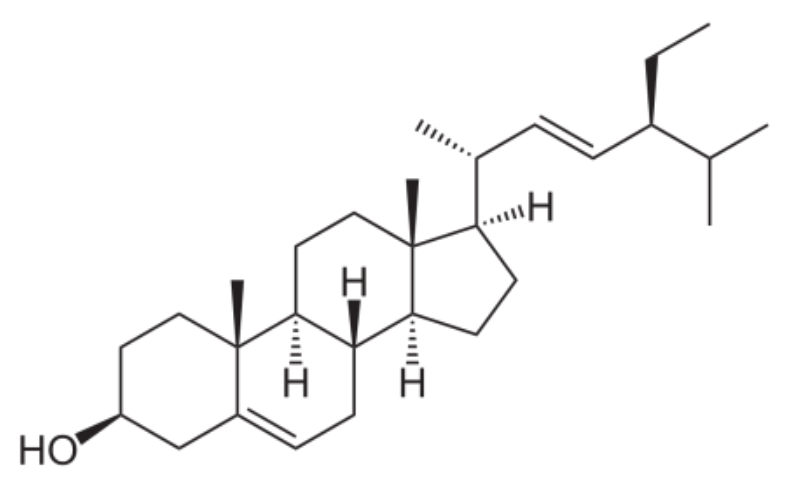

Figure 2.3. Stigmasterol

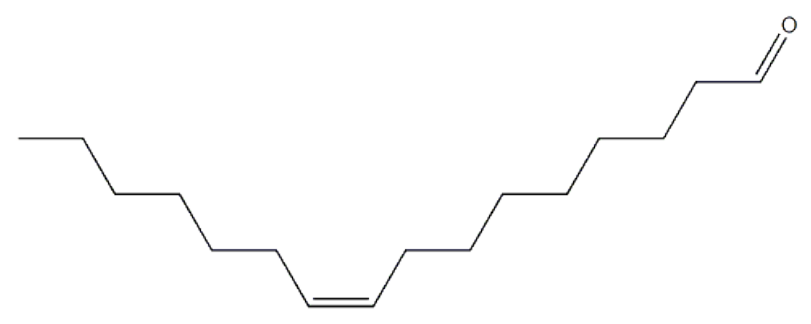

Figure 2.4. Cis-9- hexadecenal acid<smiles>CCCCCCCCCCCCCCCCCCCC(=O)O</smiles>

Figure 2.5. Icosanoic acid<smiles>C/C(=C\CO)CCC[C@H](C)CCC[C@H](C)CCCC(C)C</smiles>

Figure 2.6. Phytol

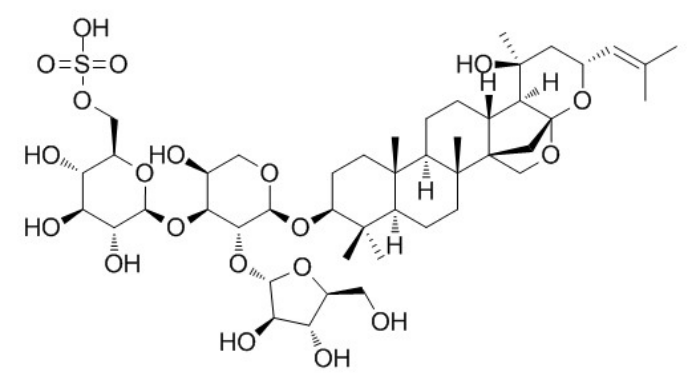

Figure 2.7. Bacoside-I

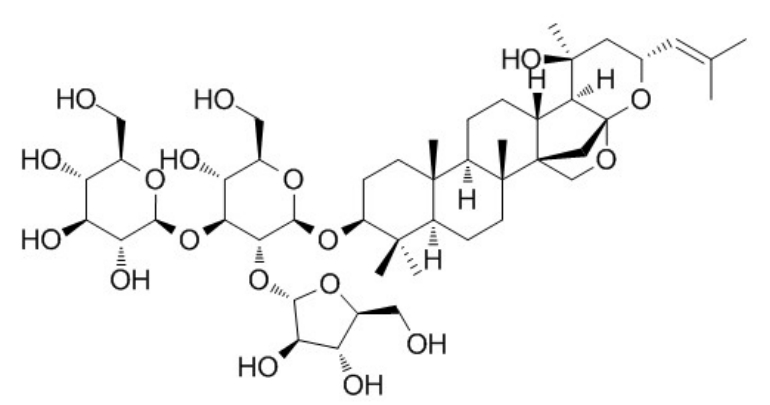

Figure 2.8. Bacoside-II

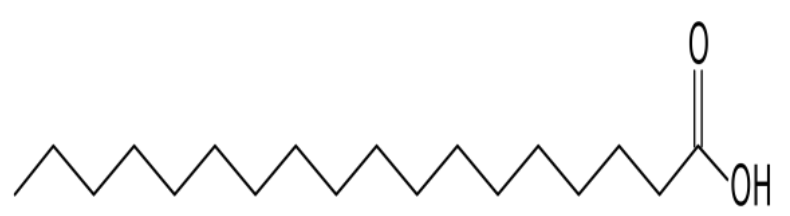

Figure 2.9. Octadecanoic acid<smiles>Cc1c(C)c2c(c(C)c1O)CC[C@](C)(CCC[C@H](C)CCC[C@H](C)CCCC(C)C)O2</smiles>

Figure 2.10. Vitamin $\mathrm{E}$

Fig 2.1 to 2.10 Various Compound reported in Bacopa monnieri

\section{Tissue Culture Technique}

Shrivastava and Rajani [68] found the best result in shoot induction of leafy explant if culture medium is supplemented with $2 \mathrm{um}$ benzyladenine and gelled with $0.2 \%$ gelrite.

Micropropagation of Bacopa monnieri has been performed by Mohapatra et al., [69] by using MS and B5 media supplemented with BAP and NAA using leaf and shoot explant. Bacopa shows the best response in MS medium which is supplemented with $2 \mathrm{mg} / \mathrm{l}$ with BAP.

Another study which reports micropropagation of Bacopa monnieri was done by Vijay Kumar et al., [70] stated about suitable hormonal concentration and soil type. According to their research for root initiation MS medium should be enriched with IAA $0.5 \mathrm{mg} / 1$ and TDZ $0.06 \mathrm{mg} / 1$ whereas for shoot induction MS-medium was supplemented with $1 \mathrm{mg} / 1 \mathrm{BA}+0.4 \mathrm{mg} / 1 \mathrm{KIN}+0.4 \mathrm{mg} / 1$ NAA for better induction and growth of shoot. For callus growth, MS medium will be supplemented with $0.5 \mathrm{mg} / 1$ and $0.5 \mathrm{mg} / \mathrm{l}$ of NAA. They found clay soil is the most appropriate soil for cultivation of Bacopa monnieri followed by red soil.

Ali et al; [71] suggested better hormonal configuration for somatic embryogenesis and in vitro regeneration of Bacopa monnieri. According to them highest calli 
formation from the leaf explant were recorded on NAA $(2.5 \mathrm{mg} /$ liter) showed the highest regeneration i.e. 94.22 followed by $2,4-\mathrm{D} \mathrm{mg} /$ liter showed $71.4 \%$ calli formation. In internode explant it was recorded highest in 2, 4-D showed $65.25 \%$ regeneration. The maximum somatic embryogenesis callus, calli induction, and formation were observed on 2, 4-D KIN $(2.0+1.5 \mathrm{mg} /$ liter $)$ amended solid medium.

Sujipuli et al., [72] performed an experiment with Bacopa monnieri for enhancing biomass and bacoside production. Explant of the diploid progenitor of Bacopa monnieri treated with different doses of colchicine. Result revealed that $(0.05 \%)$ colchicine induce tetraploidy which resultant highest Bacoside A3 $(4.276 \pm 0.019 \mathrm{mg} / \mathrm{g}$ dry weight) and Bacoside e-content $(5.040 \pm 0.070 \mathrm{mg} / \mathrm{g}$ dry weight) obtained from tetraploid species.

Sharma et al., [73] added methyl jasmonate in MS medium and found $4.4 \mathrm{mg}$ bacoside $\mathrm{A} / \mathrm{gram}$ dry weight which is 1.8 fold increased from control.

Panda et al [74] reported that if fly ash was added to the prepared garden soil for Bocopa moneri by up to $25 \%$, there was no negative effect on the photosynthetic activity of Bocopa moneri, chlorophyll content, as well as an increase in plant biomass tolerance and oil content. In this way, we can not only get rid of the problem of fly ash but also increase the oil content and biomass.

A study was performed by Lala S., [75] to see the impact of copper Nanoparticle on the production of a secondary metabolite of Bacopa monnieri. Secondary metabolites were checked through the spectrophotometric method. At the concentration of $5 \mathrm{mg} / \mathrm{l} \mathrm{CuNP}$ can be used to enhance the concentration of secondary metabolites.

Use of various elicitors such as salicylic acid and jasmonic acid to increase biomass and production of bacoside in Bacopa monnieri studied by Anuja Kaul et al [76]. Increased biomass and basoside production were evaluated over a period of 3, 6, 9, 15 days. The study revealed that Salicylic acid enhances biomass and bacoside production $(6.58 \mathrm{mg} / \mathrm{g}$ of dry weight $)$ maximum between the period of 6 to 9 days.

\section{Use of Microbe for Enhancing Secondary Metabolite Production}

Microbes perform a crucial role in the growth and development of the plant body. It has been found that microbial interactivity with plant also provides the defiance biotic and abiotic stress. Banarjee and Modi [77] used a hot extract of Aulosira fertissima (cyanobacterium) added in different proportions to MS as a liquid culture media for the invitro propagation of Bacopa monnieri and found maximum numbers of shoot were induced from axillary node after maintaining proportion 40:60 of MS media and Aulosira extract. After induction maximum shoot multiplication found on adding $\mathrm{Kn}(1 \mathrm{mg} / \mathrm{L})$.

Gupta et al., [78] studied the effect and interaction of various rhizospheric bacteria Bacillus megaterium, glomus intraradices, Trichoderma harzianum and their combination on Meloidogyne incognita infected Bacopa monnieri and found that Meloidogyne incognita infection not only significantly decreased upto 2.75 fold but alos bacoside content significantly increased 1.40 fold during this period. Estimation of bacoside content done by Fourier transform near infrared.

Prasad et al., [79] demonstrated that when Bacopa is grown with root endophyte Piriformospora indica, the bacoside content, antioxidate activity of plant, growth rate and nuclear hypertrophy of plant is increased as comparted to the control.

In another study conducted by Singh et al., [80] Bacopa monnieri has exposed to different microbes bio-inoculants Pseudomonas monteilli, Cedecea davisae, Cronobacter dublinensis and P.aeruginosa. There was a significant enhancement in the biomass and secondary metabolite content of Bacopa monnieri which were prone to these microbes compared to control.

Gupta et al., [81] conducted a study to see the impact of chitiiphilus sp. MTN22 and Streptomyces sp. MTN14 singly as well as in combination modulated the biosynthetic pathway of bacoside A and systemic defense mechanism Meloidogyne incognita in Bacopa monnieri. The result showed that the expression of bacoside biosynthetic pathway genes (3-Hydroxy-3-methylglutaryl coenzyme A reductase, mevalonate diphosphate decarboxylase, and squalene synthase) in plants treated with these microbes was increased in the presence as well as in the absence of Meloidogyne incognita. Total 1.5 fold of bacoside production has increased in plant treated with Chitiiphilus sp. MTN22 and Streptomyces sp. MTN14. Plant resistances against $M$. incognita also increase via enhancement in chlorophyll a, defense enzymes and phenolic compounds like gallic acid, syringic acid, ferulic acid and cinnamic acid.

\section{Quantitative Estimation of Secondary Metabolite}

Bacopa possesses various secondary metabolites which show a diverse range of therapeutic action. Various researchers quantified total phenolic, alkaloid, tannin, and saponin content. Production of secondary metabolites in the plant was regulated by a number of factors including soil and environmental conditions. Thus, the amount of secondary metabolite may vary in the same plant which was growing in different regions. In this review, the author summarizes various studies to find out the suitable place for the cultivation of Bacopa monnieri. 
Table 2. Quantitative phytochemical presence in various studies in Bacopa monnieri growing in various part of Asia subcontinent

\begin{tabular}{|c|c|c|c|c|c|c|c|c|c|}
\hline \multirow[b]{2}{*}{ References } & \multicolumn{8}{|c|}{ Evaluated Phytochemical } & \multirow[b]{2}{*}{ Plant Collected from } \\
\hline & $\begin{array}{c}\text { Total } \\
\text { Phenolic } \\
\text { Content }\end{array}$ & $\begin{array}{l}\text { Total Alkaloid } \\
\text { Content }\end{array}$ & $\begin{array}{l}\text { Total Flavonoid } \\
\text { Content }\end{array}$ & $\begin{array}{l}\text { Total Tannin } \\
\text { Content }\end{array}$ & $\begin{array}{l}\text { Total Saponin } \\
\text { Content }\end{array}$ & $\begin{array}{l}\text { Total Sugar } \\
\text { Content }\end{array}$ & $\begin{array}{c}\text { Total Anthocyanin } \\
\text { Content }\end{array}$ & $\begin{array}{c}\text { Total } \\
\text { Chlorophyll } \\
\text { Content }\end{array}$ & \\
\hline Jain et al., [23] & $24.75 \mathrm{mg} / \mathrm{g}$ & $110 \mathrm{mg} / \mathrm{g}$ & $29.666 \mathrm{mg} / \mathrm{g}$ & $12.5 \mathrm{mg} / \mathrm{g}$ & $1.5 \mathrm{mg} / \mathrm{g}$ & & 1.436 CGE & & Ranchi \\
\hline Ghosh et al., [35] & $\begin{array}{c}47.7 \mathrm{ug} / \mathrm{mg} \text { of } \\
\text { extract }\end{array}$ & & & & & & & & Salipur, Orissa \\
\hline Hossain et al., [82] & & & & $105.90 \mathrm{mg} / \mathrm{g}$ & & $150.63 \mathrm{mg} / \mathrm{g}$ & & & $\begin{array}{l}\text { Karamjal, Sundarban } \\
\text { Khulna, Bangladesh }\end{array}$ \\
\hline Volluri et al., [83] & $\begin{array}{l}27.76 \pm 1.87 \mathrm{~m} \\
\mathrm{~g} / \mathrm{gm} \mathrm{GAE}\end{array}$ & & & & & & & & $\begin{array}{l}\text { Visakhapatnam, Andhra } \\
\text { Pradesh, India }\end{array}$ \\
\hline $\begin{array}{c}\text { Nandi } \\
\text { Chakraborty, } \\
\text { Swati et al., [84] }\end{array}$ & $\begin{array}{c}46.24 \mathrm{mg} / \mathrm{g} \\
\text { (chloroform } \\
\text { solvent) }\end{array}$ & & $\begin{array}{c}38.54 \mathrm{mg} / \mathrm{g} \\
\text { (methanol solvent) }\end{array}$ & & & & & & $\begin{array}{l}\text { East Kolkata (Wetland } \\
\text { area) Bengal India }\end{array}$ \\
\hline
\end{tabular}


Table 3. Ethnobotanical uses of Bacopa monnieri

\begin{tabular}{|c|c|c|c|}
\hline Name of Ailments & Method of drug preparation & $\begin{array}{l}\text { Area where ethno medicinal } \\
\text { practices of plants is going on }\end{array}$ & References \\
\hline $\begin{array}{l}\text { Epilepsy, Bronchial } \\
\text { and Diarrheal }\end{array}$ & $\begin{array}{l}\text { Leaves juice of plant is given to the patient for the } \\
\text { treatment of epilepsy, bronchial and diarrheal ailments }\end{array}$ & Punjab Provinces, Pakistan & Shah et al., [86] \\
\hline $\begin{array}{c}\text { Memory } \\
\text { enhancement }\end{array}$ & $\begin{array}{l}\text { Plant juice is given orally to enhance and sharpen } \\
\text { memory }\end{array}$ & Mayurbhanj District, Orissa & Rout et al., [87] \\
\hline Heaache, Hairfall & $\begin{array}{l}\text { Whole plant juice is given orally to treat headache and } \\
\text { hairfall. }\end{array}$ & Rajbari District, Bangladesh & $\begin{array}{l}\text { Mukti, M., \& } \\
\text { Rahmatullah, M. [88] }\end{array}$ \\
\hline Blisters & $\begin{array}{l}\text { A fresh root decoction is used to treat snakebite in } \\
\text { Rajasthan. Dry leaves powder with quantity of } 5 \mathrm{~g} \\
\text { mixed with crushed } 2 \text { or } 3 \text { black pepper is given in a } \\
\text { single dose for the treatment of bone fracture }\end{array}$ & Rajasthan, India & Verma, M. [89] \\
\hline Snake Bite & $\begin{array}{l}\text { Fresh root decoction used for treatment of snake-bite, } \\
\text { scorpion stings }\end{array}$ & Rajasthan, India & Verma, M. [89] \\
\hline $\begin{array}{l}\text { Hoarseness of } \\
\text { voice }\end{array}$ & $\begin{array}{l}\text { Bacopapowder fried with ghee given for the } \\
\text { enhancement of memory }\end{array}$ & Rajasthan, India & Verma, M. [89] \\
\hline $\begin{array}{l}\text { Memory } \\
\text { enhancement }\end{array}$ & $\begin{array}{l}\text { Bacopapowder fried with ghee mix with Pushkar mul } \\
\text { (Sauseria lappa's root) given for enhancement of } \\
\text { memory }\end{array}$ & Rajasthan, India & Verma, M. [89] \\
\hline Bone fracture & $\begin{array}{l}\text { Leaf powder about } 5 \mathrm{~g} \text { with } 2 \text { or } 3 \text { black pepper are } \\
\text { given in a single dose for the treatment of bone } \\
\text { fracture. }\end{array}$ & Rajasthan, India & Verma, M. [89] \\
\hline $\begin{array}{l}\text { Swelling of legs } \\
\text { (Animal) }\end{array}$ & $\begin{array}{l}\text { Leaf paste applied externally on the affected area of } \\
\text { the body } 3 \text { times daily in the legs of animals for one } \\
\text { week }\end{array}$ & Rajasthan, India & Verma, M. [89] \\
\hline Asthma & $\begin{array}{l}\text { Fresh decoction of leaves and stem filtered in a proper } \\
\text { way. Taken twice in a day for } 5 \text { to } 10 \text { days until disease } \\
\text { has been persisted. }\end{array}$ & Rajasthan, India & Verma, M. [89]. \\
\hline Hair Fall & Plant juice is applied externally on hair to treat disease & Rupandehi district, Nepal & Singh, et al., [90] \\
\hline Snake Bite & $\begin{array}{l}\text { Plant Juice mixed with castor oil is applied externally } \\
\text { to treat snake bite. Leaf powder decoction mixed with } \\
\text { hot cow's milk is given to the affected person. }\end{array}$ & $\begin{array}{l}\text { Salem district, Tamilnadu, } \\
\text { India }\end{array}$ & $\begin{array}{l}\text { Upasani et al., [91], } \\
\text { Alagesaboopathi C., } \\
\text { [92] }\end{array}$ \\
\hline Malaria & Paste of plant is given orally to treat the malarial fever. & $\begin{array}{c}\text { Haripur, Abbottabad and } \\
\text { Mansehra of Khyber } \\
\text { Pakhtunkhwa (KPK) province } \\
\text { of Pakistan } \\
\end{array}$ & Shah et al., [93] \\
\hline Snake Bite & $\begin{array}{l}\text { Leaf powder decoction is used as antidote for Cobra } \\
\text { bite. }\end{array}$ & Kurnool district, India & $\begin{array}{l}\text { Basha S Khaleel et al., } \\
{[94]}\end{array}$ \\
\hline
\end{tabular}

\section{Ethnobotanical and Ethnopharmacological Study}

Pandey et al., [85] describe a various familiar method of using plants for treating health issues in India. According to him there are four common ways to adopt plant parts as medicine, which are taking fresh juice from plant parts, making a decoction of a plant parts, taking plant powder with milk or clarified butter, and decoction of plant parts taken with honey or jaggery. In the case of Brahmi, we reported the same application of taking drugs. Various ethnobotanical surveys revealed several unknown and hidden medicinal properties of Bacopa monnieri which are listed in table 3.

\section{Application of Bacopa monnieri for Treatment of Wastewater}

Jauhari et al., [95] used Bacopa monnieri for the treatment of heavy metal contaminated wastewater. It has been observed soil-grown Bacopa monnieri remove $64 \mathrm{Cr} \%$ and $83 \% \mathrm{Cd}$ from the wastewater whereas in vitro cultured plants reduce the concentration of $\mathrm{Cr} 67 \%$ and $93 \% \mathrm{Cd}$ from wastewater. The study recommends that Bacopa monnieri can be used for the removal of heavy metal from wastewater.

Nagarajan [96] showed that Bacopa removes the enteric infection from the wastewater. The study also showed that Bacopa can easily be flourished in wastewater coming out from the toilet and sewage. It can remove coliform bacteria up to $70 \%$ which was a potent source of enteric infection.

Abbasi et al [97] tested the phytoremedial activity of Bacopa monnieri using their own SHEFROL ${ }^{\circledR}$ ("sheet flow root level") bioreactor. They found in their test that by using Bacopa monnieri in the SHEFROL $\AA$ bioreactor, suspended solids in sewage water were reduced by $90 \%$, chemical oxygen demand was reduced by $76-77 \%$, biological oxygen demand by $80 \%$, Nitrogen $65 \%$, Phosphorus 55\%, Zinc $42 \%$, Copper $42 \%$, and Nickel $41 \%$, can only be reduced through hydraulic retention of six hours. Study outcomes established that Bacopa can be used 
for the treatment of sewage (grey water).

Shanmugam et al., [98] tested the phytoremediation role of Bacopa monnieri for degradation of textiles azo dyes and found that hydroponically and invitro cultivated Bacopa successfully decolorized azo dyes at 40mg/l concentration of different azo dyes.

Gupta et al., [99] conducted a study to see the impact of $\mathrm{Cd}$ ion on the growth and content of Bacoside $\mathrm{A}$ and Bacopa side I of Bacopa monnieri. Various growth parameters including total protein, Chlorophyll content, biomasses were evaluated after the exposure of $\mathrm{Cd}$ to the plant. No harmful impact of $\mathrm{Cd}$ was recorded till $10 \mu \mathrm{M}$ and content of Bacopa side I and Bacoside A gradually increased but when $\mathrm{Cd}$ concentration increased up to 50 and $100 \mu \mathrm{M}$ it affect plant adversely as chlorophyll content, protein and biomass decrease although content of Bacopa side I and Bacoside I is still higher than control group.

\section{Future Prospective}

Bacopa monnieri is used since ancient times for enhancing memory. Patel et al., [100] listed 22 herbal formation based products which has Bacopa as a main ingredient. So the use of Bacopa is still rising in herbal product as a memory tonic and health supplement. The ethnobotanical surveys revealed lots of its medicinal properties. The ethnobotanical studies conducted revealed that this plant was a great source of anti-venomous drugs. The juice of this plant can also be used to prevent hair fall. To date, lots of ethnobotanical studies reveal that this plant has anti-sickling, anti-paralytic and anti-venomous properties but experimentally it remains unexplored. Varieties of phytochemicals and bioactive properties present in this plant are still not tested against several diseases, leaving a huge scope in this field.

\section{REFERENCES}

[1] V. Subhose, P. Srinivas, and A. Narayana, "Basic principles of pharmaceutical science in Ayurvěda," Bulletin of the Indian Institute of History of Medicine, vol. 35, no. 2, pp. 83-92, 2005

[2] Kumar, Alok, Abhishek Kumar, Ravindra Singh, and Pawan Ahirwar. "Preliminary phytochemical investigation and pharmacognostic evaluation of Alternanthera sessilis (linn.) R. Br. Ex dc, European Journal of Biomedical and Pharmaceutical sciences, Vol.2, No.3, pp.947-955, 2015.

[3] Vasu, Sudhakaran, Botanical Pharmacognosy of Bacopa monnieri (Linn.) Pennell, Pharmacognosy Journal, Vol.12, pp.1559-72, 2020, 10.5530/pj.2020.12.214.

[4] Gubbannavar, J. S., Chandola, H. M., Harisha, C. R., Khanpara, K., \& Shukla, V. J, A comparative pharmacogn ostical and preliminary physico-chemical analysis of stem and leaf of Bacopa monnieri (L.) Pennel and Bacopafloribunda (R.BR.) Wettst, Ayu, Vol.34, No.1, pp.
95-102, 2013, https://doi.org/10.4103/0974-8520.115441

[5] Raghavan, R. S., Chromosome numbers in Indian medicinal plantsm, III. Proc. Indian Acad. Sci, Vol.4, pp. 239-244, 1959.

[6] P.V. S. Caraka Samhita. Chaukhambha Orientalia; Varanasi, India: 2011.

[7] Rai, D., Bhatia, G., Palit, G., Pal, R., Singh, S., \& Singh, H. K., Adaptogenic effect of Bacopamonniera (Brahmi). Pharmacology, biochemistry, and behavior, Vol.75, No.4, pp.823-830. https://doi.org/10.1016/s0091-3057(03)00156 $-4$

[8] Russo, A \& Borrelli, Francesca, BacopaMonniera, A reputed nootropic plant: An overview. Phytomedicine: international journal of phytotherapy and phytopharmacolo gy. Vol.12. pp.305-17, 2005, 10.1016/j.phymed.2003.12.0 08 .

[9] Joshi, H., \& Parle, M, Brahmi rasayana improves learning and memory in mice. Evidence-based complementary and alternative medicine: eCAM, Vol.3, No.1, pp.79-85, 2006, https://doi.org/10.1093/ecam/nek014

[10] Channa, Shabana et al. "Anti-inflammatory activity of Bacopamonniera in rodents." Journal of ethnopharmacolog y vol. 104, No.1-2 pp.286-289, 2006, doi:10.1016/j.jep.2005.10.009

[11] Nemetchek, M. D., Stierle, A. A., Stierle, D. B., \& Lurie, D. I., The Ayurvedic plant Bacopa monnieri inhibits inflammatory pathways in the brain. Journal of ethnopharmacology, Vol.197, pp.92-100, 2017, https://doi .org/10.1016/j.jep.2016.07.073.

[12] Saini, Neetu \& Singh, Devinder \& Sandhir, Rajat, Bacopa monnieri prevents colchicine-induced dementia by anti-inflammatory action. Metabolic Brain Disease. Vol.34, No.2, pp.505-518, 2019, 10.1007/s11011-018-0332-1.

[13] Kapoor R, Srivastava S, Kakkar P, Bacopa monnieri modulates antioxidant responses in brain and kidney of diabetic rats, Environ Toxicol Pharmacol. Vol.27, No.1, pp.62 - 69, 2009, doi:10.1016/j.etap.2008.08.007

[14] Mathur, Abhishek \& Verma, Satish \& Purohit, Reena \& Singh, Santosh \& Mathur, Deepika \& Prasad, GBKS \& Dua, Virendra, Pharmacological investigation of Bacopa monnieri on the basis of antioxidant, antimicrobial and anti-inflammatory properties, Journal of Chemical and Pharmaceutical Research, Vol.2, No.6, pp.191-198, 2010

[15] Ramachandran, C., Quirin, K. W., Escalon, E., \& Melnick, S. J., Improved neuroprotective effects by combining Bacopa monnieri and Rosmarinus officinalis supercritical $\mathrm{CO} 2$ extracts, Journal of evidence-based complementary \& alternative medicine, Vol.19, No.2, pp.119-127, 2014, https://doi.org/10.1177/2156587214524577.

[16] Ramadas, Dr Dinesha \& M, Ravishankar \& S, Shwetha \& D, Chikkanna. PHYTOCHEMICAL STUDIES AND ANTIOXIDANT ACTIVITY OF BACOPA MONNIERI PLANT LEAVES PROTEINS. Indo American Journal of Pharmaceutical Research. Vol.6 pp.4302-4307, 2016

[17] Bhatia, G., Dhuna, V., Dhuna, K., Kaur, M., \& Singh, J., Bacopa monnieri extracts prevent hydrogen peroxide-induced oxidative damage in a cellular model of neuroblastoma IMR32 cells. Chinese journal of natural medicines, 15(11), pp- 834-846, 2017https://doi.org/10.10 


\section{6/S1875-5364(18)30017-7}

[18] Ferlay J, Ervik M, Lam F, Colombet M, Mery L, Piñeros M, et al. Global Cancer Observatory: Cancer Today. Lyon: International Agency for Research on Cancer; 2020 (https://gco.iarc.fr/today, accessed February 2021).

[19] Ghosh, Tirtha \& Maity, Tapan \& Singh, Jagadish, Evaluation of antitumor activity of stigmasterol, a constituent isolated from Bacopa monnieri Linn aerial parts against Ehrlich Ascites Carcinoma in mice, Orient Pharm Exp Med, Vol.11, No.1, pp.41-49. 2011, 10.1007/s13596-011-0001-y.

[20] Mallick, M. N., Akhtar, M. S., Najm, M. Z., Tamboli, E. T., Ahmad, S., \& Husain, S. A., Evaluation of anticancer potential of Bacopa monnieri L. against MCF-7 and MDA-MB 231 cell line. Journal of pharmacy \& bioallied sciences, Vol.7, No.4, pp.325-328, 2015, doi:10.4103/0975-7406.168038

[21] Mallick, M. N., Khan, W., Parveen, R., Ahmad, S., Sadaf, Najm, M. Z., Ahmad, I., \& Husain, S. A., Exploring the Cytotoxic Potential of Triterpenoids-enriched Fraction of Bacopa monnieri by Implementing In vitro, In vivo, and In silico Approaches, Pharmacognosy magazine, vol.13, No. 3, pp.S595-S606, 2017, https://doi.org/10.4103/pm.pm_397_ 16

[22] Smith, E., Palethorpe, H. M., Tomita, Y., Pei, J. V., Townsend, A. R., Price, T. J., Young, J. P., Yool, A. J., \& Hardingham, J. E. The Purified Extract from the Medicinal Plant Bacopa monnieri, Bacopa side II, Inhibits Growth of Colon Cancer Cells in Vitro by Inducing Cell Cycle Arrest and Apoptosis, Cells, Vol.7, No.7, 81, 2018, https://doi.org/10.3390/cells7070081

[23] Giramkar, Shital \& Kulkarni, Omkar \& Jagtap, Suresh \& Kuvalekar, Aniket \& Mukherjee, Sourav \& Jagtap, Rutika \& Wagh, Ajay \& Bandawane, Deepti \& Nipate, Sonali, Anticonvulsant potential of commonly practiced formulations of Brahmi (Bacopa monnieri Linn.) in Wistar rats. Journal of Pharmacy Research, Vol.7, pp. 787-791, 2013, 10.1016/j.jopr.2013.09.008.

[24] Jain, Paras \& Sharma, Hanuman Prasad \& Basri, Fauziya \& Kumari, Priya \& Singh, Pallavi, Phytochemical analysis of Bacopa monnieri (L.) Wettst and their anti-fungal activities, Vol.16, No. 2, pp.310-318, 2017 10.13140/RG.2.2.17307.4 6882.

[25] Ghosh, Tanisha \& Maity, Tapan \& Bose, Anindya \& Dash, Gouri \& Das, M, Antimicrobial activity of various fractions of ethanol extract of Bacopa monnieri Linn. aerial parts, Indian Journal of Pharmaceutical Sciences. Vol. 69 pp-312-314, 2007. 10.4103/0250-474X.33170.

[26] Khan, Ashfia \& Karim, Rubaba \& Akter, Sabiha, Evaluation of Antiulcerogenic Activity of Bacopa monnieri (LINN.) on Ethanol-Induced Gastric Injury In Mice. International Journal of Medical Science and Innovative Research (IJMSIR), Vol.3, No.3, pp.196-211, 2018, 10.13140/RG.2.2.18088.67846.

[27] Brzozowski T, Konturek PC, Konturek SJ, Kwiecien S, Pajdo R, Brzozowska I, Hahn EG. Involvement of endogenous cholecystokinin and somatostatin in gastroprotection induced by intraduodenal fat. Journal of clinical gastroenterology, Vol.1, No.27, pp.S125-37,1998

[28] GBD 2017 Disease and Injury Incidence and Prevalence
Collaborators (2018). Global, regional, and national incidence, prevalence, and years lived with disability for 354 diseases and injuries for 195 countries and territories, 1990-2017: a systematic analysis for the Global Burden of Disease Study 2017. Lancet (London, England), 392(10159), 1789-1858. https://doi.org/10.1016/S0140-67 36(18)32279-7

[29] Sairam, K., Dorababu, M., Goel, R. K., \& Bhattacharya, S. $\mathrm{K}$, Antidepressant activity of standardized extract of Bacopamonniera in experimental models of depression in rats. Phytomedicine, international journal of phytotherapy and phytopharmacology, Vol.9, No.3, pp.207-211, 2002, https://doi.org/10.1078/0944-7113-00116

[30] Girish, Chandrashekaran \& Oommen, Shweta \& Vishnu, Raj, Evidence for the involvement of the monoaminergic system in the antidepressant-like activity of methanolic extract of Bacopa monnieri in albino mice, International Journal of Basic and Clinical Pharmacology. Vol. 5, pp. 914-922, 2016, 10.18203/2319-2003.ijbcp20161545.

[31] Uabundit, N., Wattanathorn, J., Mucimapura, S., \& Ingkaninan, K., Cognitive enhancement and neuroprotective effects of Bacopa monnieri in Alzheimer's disease model, Journal of ethnopharmacology, Vol.127, No.1, pp.26-31, 2010, https://doi.org/10.1016/j.jep.2009.0 9.056

[32] Calabrese, C., Gregory, W. L., Leo, M., Kraemer, D., Bone, K., \& Oken, B., Effects of a standardized Bacopa monnieri extract on cognitive performance, anxiety, and depression in the elderly: a randomized, double-blind, placebo-controlled trial. Journal of alternative and complementary medicine (New York, N.Y.), vol.14 No.6, pp.707-713, 2008, https://doi.org/10.1089/acm.2008.0018

[33] Goswami, S., Kumar, N., Thawani, V., Tiwari, M., \& Thawani, M., Effect of Bacopa monnieri on Cognitive functions in Alzheimer's disease patients, International Journal of Collaborative Research on Internal Medicine \& Public Health, Vol.3, No.4, pp.285-290, 2011

[34] Prabhakar, Sudesh, Vishnu, Venugopalan, Modi, Mehul Mohanty, Manju Sharma, Anchal Medhi, Bikas Mittal, Bhagwant Khandelwal, Niranjan, Goyal, Manoj, Lal, Vivek, Singla, Rajesh, Kansal, Avinash, Avasthi, Ajit., Efficacy of Bacopa monnieri (Brahmi) and Donepezil in Alzheimer's disease and Mild Cognitive Impairment: A Randomized Double-Blind Parallel Phase 2b Study. Annals of Indian Academy of Neurology. Vol.23, pp.767-773, 2020, 10.4103/aian.AIAN_610_19.

[35] McPhee, G. M., Downey, L. A., Wesnes, K. A., \& Stough, C., The Neurocognitive Effects of Bacopa monnieri and Cognitive Training on Markers of Brain Microstructure in Healthy Older Adults, Frontiers in aging neuroscience, Vol.13, 2021, 638109. https://doi.org/10.3389/fnagi.2021. 638109

[36] Ghosh, Tanisha \& Maity, Tapan \& Das, M. \& Bose, Anindya \& Dash, Deepak, In Vitro antioxidant and hepatoprotective activity of ethanolic extract of Bacopa monnieri Linn. Aerial parts, Iranian Journal of Pharmacology and Therapeutics. Vol.6, pp.77-85, 2007

[37] Menon, B. R., Rathi, M. A., Thirumoorthi, L., \& Gopalakrishnan, V. K., Potential Effect of Bacopa monnieri on Nitrobenzene Induced Liver Damage in Rats, Indian journal of clinical biochemistry: IJCB, Vol.25, No.4, 
pp.401-404, 2010 https://doi.org/10.1007/s12291-010-004 $8-4$

[38] Yamada, K., Hung, P., Park, T. K., Park, P. J., \& Lim, B. O., A comparison of the immunostimulatory effects of the medicinal herbs Echinacea, Ashwagandha and Brahmi. Journal of ethnopharmacology, Vol.137, No.1, pp. 231-235, 2011 https://doi.org/10.1016/j.jep.2011.05.017

[39] Taznin, I., Mukti, M., \& Rahmatullah, M., Bacopa monnieri: An evaluation of antihyperglycemic and antinociceptive potential of methanolic extract of whole plants, Pakistan journal of pharmaceutical sciences, Vol.28 No.6, pp.2135-2139.

[40] Siraj, Md, Chakma, Newton, Rahman, Mahmudur, Salahuddin, Malik \& Kumar, Sadhu, Assessment of analgesic, antidiarrhoeal and cytotoxic activity of ethanolic extract of the whole plant of Bacopa monnieri Linn, International Research journal of Pharmacy, Vol.3, No.10, pp.98-101, 2013, 10.13140/RG.2.1.3744.9127.

[41] Ghosh, Tirtha \& Maity, Tapan \& Dash, Deepak \& Bose, Anindya, A study on wound healing activity of Bacopa monnieri Linn. Aerial parts, Oriental Pharmacy and Experimental Medicine. Vol.7, pp. 150-156, 2007, 10.3742/OPEM.2007.7.2.150.

[42] Shirwaikar A, Ghosh S, Rao PGM, Effect of Gmelina arborea Roxb. Leaves on wound healing in rats, J. Nat. Rem., Vol.3 pp.45-48, 2003

[43] Rai, Deepak \& Bhatia, Gitika \& Palit, Gautam \& Pal, Raghwendra \& Singh, Satyawan \& Singh, Hemant. Adaptogenic effect of Bacopamonniera (Brahmi). Pharmacology, biochemistry, and behavior. Vol.75, pp.823-30, 2003, 10.1016/S0091-3057(03)00156-4.

[44] Szpak, Paul, Fish bone chemistry and ultrastructure: implications for taphonomy and stable isotope analysis, Journal of Archaeological Science, Vol.38, No.12, pp. 3358-3372, 2011, doi:10.1016/j.jas.2011.07.022.

[45] Goel, R. K., Sairam, K., Babu, M. D., Tavares, I. A., \& Raman, A, In vitro evaluation of Bacopamonniera on anti-Helicobacter pylori activity and accumulation of prostaglandins. Phytomedicine: international journal of phytotherapy and phytopharmacology, Vol.10, No. 6-7, pp. 523-527, 2003, https://doi.org/10.1078/094471103322331 494

[46] Shahid, M., Subhan, F., Ullah, I., Ali, G., Alam, J., \& Shah, $\mathrm{R}$, Beneficial effects of Bacopa monnieri extract on opioid induced toxicity, Heliyon, Vol.2, No.2, 2016, e00068. https://doi.org/10.1016/j.heliyon.2016.e00068

[47] Kamkaew, N., Scholfield, C. N., Ingkaninan, K., Maneesai, P., Parkington, H. C., Tare, M., \& Chootip, K, Bacopa monnieri and its constituents is hypotensive in anaesthetized rats and vasodilator in various artery types. Journal of ethnopharmacology, Vol.137, No.1, pp.790-795, 2011, https://doi.org/10.1016/j.jep.2011.06.045

[48] Onsa-ard, A., Scholfield, C., Ingkaninan, K., Srimachai, S., Kamkaew, N., \& Chootip, K., Oral Bacopa monnieri is Antihypertensive in Rats Chronically Treated with L-NAME, Journal of Physiological and Biomedical Sciences, Vol.25, No.1, pp.23-26, 2012,

[49] Samiulla DS, Prashanth D, Amit A, Mast cell stabilizing activity of Bacopa monnieri, Fitoterapia Vol.72, pp.284-285, 2001

[50] Jadiya, P., Khan, A., Sammi, S. R., Kaur, S., Mir, S. S., \& Nazir, A., Anti-Parkinsonian effects of Bacopa monnieri: insights from transgenic and pharmacological Caenorhabditis elegans models of Parkinson's disease, Biochemical and biophysical research communications, Vol. 413 No.4, pp.605-610, 2011. https://doi.org/10.1016/ j.bbrc.2011.09.010

[51] Singh, B., Pandey, S., Rumman, M., \& Mahdi, A. A., Neuroprotective effects of Bacopa monnieri in Parkinson's disease model. Metabolic brain disease, Vol.35 No.3, pp.517-525, 2020 https://doi.org/10.1007/s11011-019-005 $26-\mathrm{w}$

[52] Singh, A., \& Singh, S. K. (2009). Evaluation of antifertility potential of Brahmi in male mouse. Contraception, 79(1), 71-79. https://doi.org/10.1016/j.contraception.2008.07.023

[53] Saha, S., Mahapatra, K. K., Mishra, S. R., Mallick, S., Negi, V. D., Sarangi, I., Patil, S., Patra, S. K., \& Bhutia, S. K, Bacopa monnieri inhibits apoptosis and senescence through mitophagy in human astrocytes. Food and chemical toxicology: an international journal published for the British Industrial Biological Research Association, Vol.141, 2020 111367. https://doi.org/10.1016/j.fct.2020.111367

[54] Ullah, I., Subhan, F., Lu, Z., Chan, S. W., \& Rudd, J. A. Action of Bacopa monnieri to antagonize cisplatin-induced emesis in Suncus murinus (house musk shrew). Journal of pharmacological sciences, Vol.133, No.4, pp.232-239, 2017 https://doi.org/10.1016/j.jphs.2017.03.001

[55] Joshua Allan J, Damodaran A, Deshmukh NS, Goudar KS, Amit A, Safety evaluation of a standardized phytochemical composition extracted from Bacopa monnieri in Sprague--Dawley rats, Food Chem Toxicol, Vol. 45, No.10, pp-1928-37, 2006, doi: 10.1016/j.fct.2007.04.010. Epub 2007 Apr 27. PMID: 17560704.

[56] Sireeratawong, S., Jaijoy, K., Khonsung, P., Lertprasertsuk, N., \& Ingkaninan, K, Acute and chronic toxicities of Bacopa monnieri extract in Sprague-Dawley rats. BMC complementary and alternative medicine, Vol.16, No.249, 2016, https://doi.org/10.1186/s12906-016-1236-4

[57] Phrompittayarat Watoo, Jetiyanon Kanchalee, Wittaya-Areekul, Sakchai Putalun, Waraporn, Tanaka Hiroyuki, Khan Ikhlas \& Ingkaninan Kornkanok, Influence of seasons, different plant parts, and plant growth stages on saponin quantity and distribution in Bacopa monnieri. Songklanakarin Journal of Science and Technology. Vol.33, No.2, pp.193-199, 2011

[58] Pawar, Sushama, Study of Phytochemical Screening, Physicochemical Analysis and Antimicrobial Activity of Bacopa monnieri (L) Extracts. INTERNATIONAL JOURNAL OF ADVANCES IN PHARMACEUTICAL RESEARCH. Vol.8. pp.1222-1229, 2016

[59] Chaurasia, Bhaskar \& Dixit, Ashwini \& Khan, Naureen, Pharmacognostic Characterization for Taxonomic Identification of Bacopa monnieri (L.) Wettst. for Quality Control, Vol.11, pp.54-62, 2021, 10.22376/ijpbs/lpr.2021. 11.1.L54-62.

[60] Phrompittayarat, Watoo, Putalun, Waraporn, Tanaka, Hiroyuki, Jetiyanon, Kanchalee, Wittaya-Areekul, Sakchai \& Ingkaninan, Kornkanok, Comparison of Various Extraction Method of Bacopa monnieri, Naresuan 
University Journal. Vol.15, pp.29-34, 2007

[61] Gingade, Smitha \& Kozhummal, Ranjitha \& S G, Silpa., Drying and packaging methods impact the bacoside profile and microbiological quality of Brahmi herb (Bacopa monnieri L.) during storage, Industrial Crops and Products. Vol. 159, 2020 10.1016/j.indcrop.2020.113064.

[62] Chillara Sivaramakrishna, Chirravuri V. Rao, Golakoti Trimurtulu, Mulabagal Vanisree, Gottumukkala V. Subbaraju, Triterpenoid glycosides from Bacopa monnieri, Phytochemistry, Vol-66, No.23, pp.2719-2728, 2005, 10.1016/j.phytochem.2005.09.016.

[63] Bhandari, P., Kumar, N., Singh, B., \& Kaul, V. K. Bacosterol glycoside, a new 13,14-seco-steroid glycoside from Bacopa monnieri. Chemical \& pharmaceutical bulletin, 54(2), pp- 240-241, 2006, https://doi.org/10.1248 /cpb.54.240

[64] Murthy, P. B., Raju, V. R., Ramakrisana, T., Chakravarthy, M. S., Kumar, K. V., Kannababu, S., \& Subbaraju, G. V., Estimation of twelve Bacopasaponins in Bacopa monnieri extracts and formulations by high-performance liquid chromatography. Chemical \& pharmaceutical bulletin, Vol.54, No.6, pp.907-911, 2006, https://doi.org/10.1248/c pb.54.907

[65] Bhandari, P., Kumar, N., Singh, B., \& Kaul, V. K, Cucurbitacins from Bacopa monnieri. Phytochemistry, vol68 (9), pp- 1248-1254, 2007,

https://doi.org/10.1016/j.phytochem.2007.03.013

[66] Basheera, Shefin, Identification of lead molecules with anti-hepatitis B activity in Bacopa monnieri (L.) Wettst. and Cassia fistula L. through in silico method. IOSR Journal of Pharmacy and Biological Sciences (IOSR-JPBS), vol-11, Pp-16-21, 2016, 10.9790/3008-1105041621.

[67] Jeyasri, R., Muthuramalingam, P., Suba, V., Ramesh, M., \& Chen, J. T. (2020). Bacopa monnieri and Their Bioactive Compounds Inferred Multi-Target Treatment Strategy for Neurological Diseases: A Cheminformatics and System Pharmacology Approach. Biomolecules, 10(4), 536. https://doi.org/10.3390/biom10040536

[68] Shrivastava, N., \& Rajani, M. Multiple shoot regeneration and tissue culture studies on Bacopa monnieri (L.) Pennell, Plant Cell Reports, Vol.18, pp.919-923. 1999

[69] Mohapatra, H. P., \& Rath, S. P., In vitro studies of Bacopa monnieri--an important medicinal plant with reference to its biochemical variations. Indian journal of experimental biology, Vol.43, No.4, pp.373-376, 2005.

[70] Vijayakumar, Ramasamy, In vitro propagation of Bacopa monnieri L. -a multipurpose medicinal plant. Indian J. Sci. Technol. Vol.3, pp.782-787, 2010 10.17485/ijst/2010/v3i7/ 29814.

[71] Ali, Daoud et al. "Somatic embryogenesis and in vitro plant regeneration of Bacopa monnieri (Linn.) Wettst., a potential medicinal water hyssop plant." Saudi journal of biological sciences vol. 28, 1, 2021: pp-353-359. doi:10.1016/j.sjbs.2020.10.013

[72] Sujipuli, Kawee \& Inthima, Phithak \& Yimtragool, Nonglak \& Warnnissorn, Netnaphis \& Warnnissorn, Prateep \& Prasarnpun, Surisak, In vitro colchicine-induced polyploids from different explant segments of Bacopa monnieri, ScienceAsia, Vol.47, No.30, 2021, 10.2306/scienceasia1513-1874.2021.003.

[73] Sharma, Poojadevi \& Yadav, Sheetal \& Srivastava, Anshu \& Shrivastava, Neeta, Methyl jasmonate mediates upregulation of bacoside A production in shoot cultures of Bacopa monnieri. Biotechnology letters. Vol.35, No.1121-5, 2013, 10.1007/s10529-013-1178-6.

[74] Panda, D., Barik, J. R., Barik, J., Behera, P. K., \& Dash, D, Suitability of Brahmi (Bacopa monnieri L.) cultivation on fly ash-amended soil for better growth and oil content. International journal of phytoremediation, Vol.23 No.1, pp.72-79, $2021 \mathrm{https} / / /$ doi.org/10.1080/15226514.2020.17 91052

[75] Lala S., Enhancement of secondary metabolites in Bacopa monnieri (L.) Pennell plants treated with copper-based nanoparticles in vivo. IET nanobiotechnology, Vol.14, No.1, pp.78-85, 2020, https://doi.org/10.1049/iet-nbt.201 9.0124

[76] Koul Anuja \& Mallubhotla, Sharada, Elicitation and enhancement of bacoside production using suspension cultures of Bacopa monnieri (L.) Wettst, 3 Biotech, Vol.10, No.6, 2020, 10, pp.1-4 10.1007/s13205-020-02242-0

[77] Banerjee, Meenakshi \& Modi, Priyanka, Micropropagation of Bacopa monnieri using Cyanobacterial Liquid Medium, Plant Tissue Culture and Biotechnology, Vol.20, No.2, pp. 225-231, 2011, 10.3329/ptcb.v20i2.6917.

[78] Gupta, R., Tiwari, S., Saikia, S. K., Shukla, V., Singh, R., Singh, S. P., Kumar, P. V., \& Pandey, R, Exploitation of microbes for enhancing bacoside content and reduction of Meloidogyne incognita infestation in Bacopa monnieri L. Protoplasma, Vol. 252, No.1, pp.53-61, 2015, https://doi.org/10.1007/s00709-014-0657-5

[79] Prasad, R., Kamal, S., Sharma, P. K., Oelmüller, R., \& Varma, A., Root endophyte Piriformospora indica DSM 11827 alters plant morphology, enhances biomass and antioxidant activity of medicinal plant Bacopa monniera. Journal of basic microbiology, Vol.53,No.12, pp.10161024, 2013, https://doi.org/10.1002/jobm.201200367

[80] Singh, Rakshapal \& Tiwari, Sudeep \& Soni, Sumit \& Singh, Deepmala \& Singh, Rashmi \& Singh, Sivesh \& Kumar, P.V. \& Pandey, Rakesh \& Kalra, Alok, Bioinoculants as a tool to improve total bacoside content in Bacopa monnieri L. (Pennell). International Journal of Scientific and Engineering Research. Vol.5, pp.878-896, 2014

[81] Gupta, R., Singh, A., Srivastava, M., Singh, V., Gupta, M. M., \& Pandey, R, Microbial modulation of bacoside A biosynthetic pathway and systemic defense mechanism in Bacopa monnieri under Meloidogyne incognita stress. Scientific reports, Vol. 7, No.1, pp.1-11, 2017, https://doi.org/10.1038/srep41867

[82] Hossain, Hemayet \& Al-Mansur, Muhammad \& Akter, S. \& Sara, U. \& Ahmed, Dr Md \& Jahangir, A.A, Evaluation of anti-inflammatory activity and total tannin content from the leaves of Bacopa monnieri (Linn.). IJPSR. Vol.5, pp.1246-1252, 2014.

[83] Volluri, S.S. \& Bammidi, S.R. \& Chippada, S.C. \& Vangalapati, M., In-vitro antioxidant activity and estimation of total phenolic content in methanolic extract of Bacopamonniera. Rasayan Journal of Chemistry. Vol.4. pp.381-386, 2011 
[84] Nandi Chakraborty, Swati. Estimation of phytochemical characteristics and antioxidant property of secondary metabolites of a memory enhancing medicinal herb baccopa monnieri of East KIolkata wetland. International journal of advances in pharmaceutical research. Vol.11. No.6 pp. 2860-2867, 2020, 10.13040/IJPSR.0975-8232.11 (6).2860-67.

[85] Pandey, Abhishek Kumar, An Ethnobotanical Study of Medicinal Plants in Atal Nagar (New Raipur) of Chhattisgarh, India, International Research Journal of Plant Science, Vol.12, No.1, pp.1-18, 2021.

[86] Shah, Amin \& Marwat, Sarfaraz \& Gohar, Faryal \& Khan, Ameer \& Bhatti, Khizar \& Amin, Muhammad \& Din, Noor \& Ahmad, Mushtaq \& Zafar, Muhammad. (2013). Ethnobotanical Study of Medicinal Plants of Semi-Tribal Area of Makerwal \& Gulla Khel (Lying between Khyber Pakhtunkhwa and Punjab Provinces). American Journal of Plant Sciences. 4. 98-116.

[87] Rout SD and Panda SK: Ethnomedicinal plant resources of Mayurbhanj District, Orissa. Indian J Tradit Know; Vol.9 No.1, pp.68-72, 2010.

[88] Mukti, M., \& Rahmatullah, M., Treatment with aquatic plants by a Bagdi tribal healer of Rajbari District, Bangladesh. Ancient science of life, Vol.33, No.1, pp.2226, 2013, https://doi.org/10.4103/0257-7941.134562

[89] Verma, M., ethno-medicinal and antimicrobial screening of Bacopa monnieri (1.) Pennell, Journal of Phytology, Vol.6, pp.1-6, 2014, Retrieved from https://updatepublishing.com /journal/index.php/jp/article/view/2803

[90] Singh AG, Kumar A, Tewari DD. An ethnobotanical survey of medicinal plants used in Terai forest of western Nepal. J Ethnobiol Ethnomed, vol.8, No.19, pp.1-14, 2012, doi: $10.1186 / 1746-4269-8-19$

[91] Upasani, Sughosh \& Beldar, Vishal \& Tatiya, Anil \& Upasani, Manali \& Surana, Sanjay \& Patil, Divyata, Ethno medicinal plants used for snake bite in India: An brief overview, Integrative Medicine Research, Vol.6, No.2, 2017, 10.1016/j.imr.2017.03.001.

[92] Alagesaboopathi, C.. "Ethnomedicinal plants used for the treatment of snake bites by Malayali tribal's and rural people in Salem district, Tamilnadu, India." International
Journal of Biosciences Volume-3 pp- 42-53, 2013

[93] Shah, Ghulam \& Abbasi, Arshad \& Khan, Nadeem \& Guo, Xinbo \& Khan, Mir \& Hussain, Manzoor \& Bibi, Sultan \& Nazir, Abdul \& Tahir, Adnan, Traditional uses of medicinal plants against malarial disease by the tribal communities of Lesser Himalayas-Pakistan. Journal of ethnopharmacology. Vol.155, 2014, 10.1016/j.jep.2014.05.047.

[94] Basha S Khaleel, G.sudarsanam, Traditional use of plants against snakebite in Sugali tribes of Yerramalais of Kurnool district, Andhra Pradesh, India, Asian Pacific Journal of Tropical Biomedicine Vol.2, No. 2, pp.S575-S579, 2012

[95] Jauhari, N., Menon, S., Sharma, N., \& Bharadvaja, N., Uptake of Heavy Metals from Industrial Wastewater Using In Vitro Plant Cultures. Bulletin of environmental contamination and toxicology, Vol.99, No.5, pp.614-618, 2017 https://doi.org/10.1007/s00128-017-2183-6

[96] P. Nagarajan et al., "Biological treatment of domestic wastewater by selected aquatic plants, International Conference on Technological Advancements in Power and Energy (TAP Energy), pp. 1-4, 2017, doi: 10.1109/TAPENERGY.2017.8397350.

[97] Tabassum-Abbasi, Patnaik P, Abbasi SA. Ability of Indian pennywort Bacopa monnieri (L.) Pennell in the phytoremediation of sewage (greywater). Environ Sci Pollut Res Int, Vol.27 No.6, pp.6078-6087, 2020, doi: 10.1007/s11356-019-07259-4.

[98] Shanmugam, L., Ahire, M., \& Nikam, T., Bacopa monnieri (L.) Pennell, a potential plant species for degradation of textile azo dyes. Environmental science and pollution research international, Vol.27, No.9, pp.9349-9363, 2020, https://doi.org/10.1007/s11356-019-07430-x

[99] Gupta, Poonam et al. "Effect of cadmium on growth, bacoside A, and Bacopa side I of Bacopa monnieri (L.), a memory enhancing herb." TheScientificWorldJournal vol. 2014 824586. 30 Jan. 2014, doi: 10.1155/2014/824586

[100] Patel, Saurabh \& Birwal, Preeti \& Basu, Santanu \& Pawar, Devendra \& datir, rupesh \& Deshmukh, Gajanan, Brahmi (Bacopa monnieri) as functional food ingredient in food processing industry, Journal of Pharmacognosy and Phytochemistry. Vol.7, No.3, pp.189-194, 2018. 